\title{
CONGRESS, EX PARTE YOUNG, AND THE FATE OF THE THREE-JUDGE DISTRICT COURT
}

\author{
Michael E. Solimine*
}

\begin{abstract}
In 1908 the Supreme Court held in Ex parte Young that a federal judge could enjoin a state attorney general from enforcing an unconstitutional state statute, notwithstanding sovereign immunity doctrines, which would normally bar such relief. The case was sharply criticized at the time as another example of an activist federal judiciary striking down Progressive Era regulatory legislation. Congress enacted legislation requiring that Ex parte Young injunctions only be issued by a specially convened three-judge district court. Despite the initial hostility, as has been recounted by Owen Fiss, William Ross, and other scholars, the injunctive power recognized in the case came to be regarded as a powerful and necessary tool to enforce federal civil rights laws, especially in the face of recalcitrant state authorities. In contrast, the history of the three-judge district court has received less attention and has had a different arc. During the Civil Rights era, some federal judges, particularly in the Deep South, were perceived as being hostile to the enforcement of federal law, and a three-judge court was considered by many to be a necessary tool to marginalize such judges and optimize enforcement of federal legal norms. The federal judiciary itself later questioned the court's usefulness due to the administrative burdens of convening such courts, and the perception that their role in enforcing federal law was no longer necessary. Responding to those concerns, and over the opposition of the NAACP, Congress in 1976 sharply restricted the jurisdictional coverage of the court. The changes in the

\footnotetext{
* $\quad$ Donald P. Klekamp Professor of Law, University of Cincinnati College of Law. Copyright C 2008. Prior versions of this article were presented at a faculty workshop at Villanova University School of Law, the Ohio Legal History Seminar at the Moritz College of Law at The Ohio State University, and at the 2008 annual meeting of the Midwest Political Science Association. For their comments on an earlier draft, I thank Todd Aagaard, Lou Bilionis, Jacob Cogan, Jon Entin, Barry Friedman, Arthur Hellman, Lonny Hoffman, Michael Moreland, John Oakley, Robert Post, Ed Purcell, Rich Saphire, Gil Seinfeld, Sandra Sperino, David Stebenne, Adam Steinman, David Stras, Jim Walker, and Steve Wasby. I also thank Seth Hanft, Laura H. Pulliam and Amy M. Scholl for their excellent research assistance, Ron Jones of the University of Cincinnati College of Law Library, Ed Hartnett, and the financial support of the Harold C. Shott Foundation.
} 
three-judge district court demonstrate the importance of appreciating the motivations and effects of Congressional regulation of the institutional structures of the federal courts and that of interest groups in influencing Congress.

\section{INTRODUCTION}

The centennial of the United States Supreme Court's decision in Ex parte Young ${ }^{1}$ is a useful time to reconsider the importance of and reaction to the case. The Court held that state officials could be sued in federal court to redress violations of federal law, despite the strictures of the Eleventh Amendment to the Constitution, which would, otherwise, prevent such a suit. Modern writers have not minced words in characterizing the importance of the decision. The late Charles Alan Wright referred to Ex parte Young and its progeny as "indispensable to the establishment of constitutional government and the rule of law[,]"2 because the effect of the case "is to bring within the scope of federal judicial review actions that otherwise might escape review, and to subject the states to the restrictions of the United States Constitution that they otherwise might be able to safely ignore."” Other writers observe that most if not all of the modern edifice of civil rights injunctive litigation in federal court would be virtually nonexistent absent Exparte Young and related cases establishing limits to state sovereign immunity embodied in the Eleventh Amendment. ${ }^{4}$ Supreme Court Justices of different philosophical persuasions have sung paeans to the case. ${ }^{5}$

1. 209 U.S. 123 (1908).

2. Charles Alan Wright \& Mary Kay Kane, Law of Federal Courts $\S 48$, at 314 (6th ed.

3. Id. at 312. Professor Wright considered Ex parte Young on par in importance with Marbury v. Madison, 5 U.S. (1 Cranch) 137 (1803), and Martin v. Hunter's Lessee, 14 U.S. (1 Wheat.) 304 (1816). See 17A Charles Alan Wright et al., Federal Practice and Procedure $§ 4231$, at 135 (3d ed. 2007).

4. See, e.g., Owen M. Fiss, The Civil Rights Injunction 3-5 (1978); John C. JefFries, JR. et Al., Civil Rights Actions: Enforcing the Constitution 7 (2d ed. 2007); William F. Duker, Mr. Justice Rufus W. Peckham and the Case of Ex parte Young: Lochnerizing Munn v. Illinois, 1980 BYU L. Rev. 539, 540. See also Montgomery N. Kosma, Measuring the Influence of Supreme Court Justices, 27 J. LEgal StUd. 333, 359 tbl.6 (1998) (demonstrating that in a study of 1.2 million citations to 24,000 Supreme Court opinions from 1793 to 1991, Ex parte Young was the tenth most influential opinion).

5. E.g., Green v. Mansour, 474 U.S. 64, 68 (1985) (Rehnquist, J.) ("[T]he availability of prospective relief of the sort awarded in Ex parte Young gives life to the Supremacy Clause."); Perez v. Ledesma, 401 U.S. 82, 106-07 (1971) (Brennan, J., concurring in part and dissenting in part) (explaining that together with the passage of what is now 28 U.S.C. $\$ 1331$ and 42 U.S.C. $\S 1983$, Ex parte Young "established the modern framework for federal protection of constitutional rights from state interference."). 
The place of Ex parte Young in the federal courts canon needs no amplification. What is less appreciated is the varying reaction to the case, particularly in Congress, and that is the focus of this article. Initially, it was sharply criticized as another example of the Lochner Court holding unconstitutional a state regulatory statute of the Progressive Era. Congress considered enacting proposals that would have led to overruling the case, but in 1910 settled on legislation requiring that federal court suits seeking the invalidation of state legislation be litigated before a specially constituted three-judge district court, rather than simply one trial judge, with a direct appeal available to the Supreme Court.

Despite the initial rebuff, the later decades of the twentieth century saw the embrace of Ex parte Young by federal judges and many plaintiffs in civil rights cases. The three-judge district court, in contrast, has a more complicated history. In the first few decades of its life, Congress expanded the jurisdiction of the court. Later on, influential elements of the legal community found the court to be an anachronism, and in 1976 their efforts convinced Congress to considerably restrict the jurisdiction of the court. The intertwined but ultimately different arcs of history of Ex parte Young and of the three-judge district court illustrate several lessons: the law of unintended consequences, the importance of understanding the development of legal doctrine in its institutional context, and the ebb and flow of congressional reaction to Supreme Court decisions. These issues have not received full attention in the otherwise abundant scholarly literature on Ex parte Young.

This Article proceeds as follows. Part II revisits the nineteenth century jurisprudence of the Eleventh Amendment, which led to Ex parte Young early in the next century. That Part examines the early, hostile reaction to the case in the legal community at large and in Congress, and the enactment of the three-judge district court.

Part III of the Article considers the rise of Ex parte Young and the fall of the three-judge district court. With regard to the former, in the latter decades of the last century, the injunctive relief available under the decision and its progeny proved to be an invaluable sword in the hands of plaintiffs' lawyers, particularly those in the Civil Rights movement. Absent that sword, it appears that many of the iconic federal court decisions of that era would not have been heard in federal court. Rather, the issues of federal law would often have had to have been raised as shields to coercive actions by state authorities in state court.

Part III then turns to the historical development of the three-judge district court. Framed as a limitation on federal court authority, Congress initially added to the jurisdiction of the court cases that did not directly implicate $E x$ 
parte Young-type relief. But litigation seeking injunctive relief against state action remained the focal point of the work of the court in the middle decades of the twentieth century. Some civil rights litigators, especially in the Deep South, found it useful to have such courts available because, among other things, they perceived the necessity of a multi-member trial court marginalizing otherwise indifferent or hostile federal district judges. At the same time, though, other members of the legal community, including members of the Supreme Court, found the court largely to be an anachronism, what with the logistical difficulties of assembling three judges for a trial, coupled with numerous direct appeals adding considerably to the docket of the Supreme Court. These concerns were eventually brought to the attention of Congress, which considered proposals to abolish the three-judge district court. Civil rights litigators and organizations, notably the NAACP, opposed these proposals. In 1976, Congress enacted a compromise of sorts, abolishing the previous broad coverage of the court, and leaving it intact only to hear reapportionment cases.

Part IV concludes the Article by situating the history of the three-judge district court in the academic literature exploring the alternatively contentious and cooperative relationship between Congress and the Supreme Court.

\section{EX PARTE YounG AND the Muted Fury of Congress}

\section{A. The Path to Ex parte Young}

The genesis of Ex parte Young begins with the Supreme Court's decision in Chisholm v. Georgia. ${ }^{6}$ There, the Court famously held that a private citizen of one state could bring suit in federal court against a different state for failure to pay a debt, notwithstanding the state's protest that the action should be barred by the venerable doctrine of sovereign immunity. The Court noted in Hans v. Louisiana - one hundred years after it rendered its decision in Chisholm - that Chisholm was greeted with "such a shock of surprise" that what became the Eleventh Amendment to the Constitution was promptly introduced in Congress and fully adopted five years later. ${ }^{7}$ The Amendment,

6. 2 U.S. (2. Dall.) 419 (1793).

7. Hans, 134 U.S. 1,11 (1890). This language has since been ritualistically invoked many times by the Court, e.g., Seminole Tribe of Fla. v. Florida, 517 U.S. 44, 69 (1996), and by commentators, e.g., Richard H. Fallon, Jr. et al., Hart and Wechsler's The Federal Courts and the Federal System 979 (5th ed. 2003), in characterizing the reaction to Chisholm. Cf. FALLON ET AL., at 979 n.2 (summarizing scholarship on the initial reaction to Chisholm, which disputes the accuracy of this characterization). 
hardly a model of clarity, states that federal courts are not open to hear suits of the kind illustrated by Chisholm. ${ }^{8}$

Due to the absence of general federal question jurisdiction in the federal courts until Reconstruction, the Supreme Court had few occasions to apply the Amendment until the last three decades of the nineteenth century. ${ }^{9}$ The Court then made up for lost time. Between 1873 and 1908, the Court decided about thirty cases that turned in some way on an interpretation of the Amendment. ${ }^{10}$ The renewed interest in the Amendment appears to have been driven in large part by litigants seeking relief in federal court from states repudiating bonded indebtedness, and from the then-novel attempts by states to regulate business. ${ }^{11}$ In both instances, the Due Process Clause of the Fourteenth Amendment was the principal source of federal rights allegedly being violated by the states, and either states themselves, or officials acting on behalf of the state, were the defendants, thus raising sovereign immunity concerns.

A full doctrinal discussion of these many cases is beyond the scope of this article. ${ }^{12}$ A summary of several of the primary decisions regarding state officials as defendants will help place Ex parte Young in its doctrinal and historical context. Since the Amendment by its terms (and by interpretation) ${ }^{13}$

8. The Amendment states: "The Judicial Power of the United States shall not be construed to extend to any suit in law or equity, commenced or prosecuted against one of the United States by Citizens of another State, or by Citizens or subjects of any Foreign State." There is voluminous scholarly literature addressing the proper meaning of the Amendment and whether later Supreme Court cases have correctly discerned that meaning. For a summary of that literature, see FALLON ET AL., supra note 7, at 979-86. A full discussion of the original meaning of the Amendment is beyond the scope of this article.

9. FALLON ET AL., supra note 7. For a summary of the pre-Civil War cases that did interpret the Amendment, see $i d$. at 979-82.

10. Clyde E. Jacobs, The Eleventh Amendment and Sovereign Immunity 107 (1972).

11. Id. at 106. See also Swift \& Co. v. Wickham, 382 U.S. 111, 117 (1965) (tracing federal court activity to reactions to the Granger and labor movements and the "acceleration of state social legislation"); Michael G. Collins, The Unhappy History of Federal Question Removal, 71 Iow A L. REv. 717, 767-68 (1986) (suggesting that at the turn of the century, "as the Supreme Court became more hospitable to substantive due process claims ... it was spurred to develop a means" by which parties could affirmatively bring their claims in federal court, rather than raise them as defenses in state court actions).

12. For lucid discussions of the abundant and confusing Eleventh Amendment jurisprudence in the post-Civil War and pre-Ex parte Young era, see David P. Currie, The Constitution in the Supreme Court: The Second Century 1888-1986, at 50-54 (1990); Fallon et Al., supra note 7, at 992-93; Owen M. Fiss, Troubled Beginnings of the Modern State, 1888-1910, at 211-16 (1993); Jacobs, supra note 10, at 106-43; Duker, supra note 4, at 546-55; James Leonard, Ubi Remedium Ibi Jus, or, Where There's a Remedy, There's a Right: A Skeptic's Critique of Ex parte Young, 54 Syracuse L. Rev. 215, 246-56 (2004). See generally John V. Orth, The Judicial Power of the United States: The Eleventh AMENDMENT IN AMERICAN History 47-135 (1987).

13. The most important case here is Hans v. Louisiana, 134 U.S. 1 (1890), which held that, given the intent of the framers of the Eleventh Amendment, the barrier to suit in federal court should extend to citizens of the state being sued, in addition to citizens of another state, the former not being expressly 
only barred suits against a State as such, litigants attempted to evade the strictures of the Amendment by suing the state officials charged with application of the offending laws. The Court had earlier held that the Amendment's immunity did not attach when suit was brought against a state official who would merely be personally liable for the alleged harm. ${ }^{14}$ These holdings were apparently limited in In re Ayres, ${ }^{15}$ which held that the mere filing of a suit claiming unconstitutional action by a state official was not of itself evidence of wrongful activity by that official sufficient to set aside the immunity derived from the Amendment. The injunctive relief sought in Ayres was therefore barred by the Amendment.

But later cases seemed to limit the holding of Ayres, or to confuse its application. For example, in Smyth v. Ames, ${ }^{16}$ the Court held that the Amendment did not apply if the state official was enforcing the allegedly unconstitutional enactment. Shortly thereafter, the Court in Fitts v. McGhee $e^{17}$ distinguished cases like Smyth and held that the Amendment applied when the state officials being sued (the state attorney general in that case) were not directly authorized to enforce, or otherwise had no special relationship to, the offending state legislation. The Court's efforts to reconcile these cases can only be described as muddled. ${ }^{18}$

The conflict that gave rise to Ex parte Young ${ }^{19}$ was shaped by the Eleventh Amendment cases. ${ }^{20}$ It is fitting that the case arose from Minnesota,

mentioned by the Amendment. Hans was, and continues to be, the subject of enormous discussion both on, e.g., Seminole Tribe of Fla. v. Florida, 517 U.S. 44 (1996), and off, e.g., FALlON ET AL., supra note 7, at 1023-24 (summarizing the continuing debate over the correctness of Hans) the Court in recent years, involving whether it was correctly decided, and whether it is a constitutional holding, or simply one of federal common law (and hence reversible by Congressional legislation). However, Hans does not directly implicate the line of cases culminating in Exparte Young, since in those cases the litigants were attempting to evade the Amendment by suing state officials, as opposed to the state itself. Hans involved a suit over the repudiation of a Reconstruction Era state debt. For a thorough discussion of Hans in its doctrinal and historical context, asserting that the case is best understood as an example of the failure to enforce federal law in the post-Reconstruction South, see Edward A. Purcell, Jr., The Particularly Dubious Case of Hans v. Louisiana: An Essay on Law, Race, History, and "Federal Courts," 81 N.C. L. Rev. 1927 (2003).

14. E.g., Governor of Ga. v. Madrazo, 26 U.S. (1 Pet.) 110 (1828).

15. 123 U.S. 443 (1887).

16. 169 U.S. $466(1898)$.

17. 172 U.S. $516(1899)$

18. See Wright \& KANE, supra note 2, at 309-10 (describing the cases as "varying and uncertain" and "erratic").

19. 209 U.S. 123 (1908)

20. For the definitive account of the Exparte Young litigation, see Richard C. Cortner, The Iron Horse and the Constitution: The Railroads and the Transformation of the Fourteenth AmENDMENT 153-211 (1993). For other useful accounts, see JACOBS, supra note 10, at 138-45; ORTH, supra note 12, at 121-35; Duker, supra note 4; Leonard, supra note 12, at 222-27. 
given the strong Progressive credentials of that state government, and that it was among the first to regulate the rates and other business practices of railroads..$^{21}$ Emboldened in part by the strong regulatory focus of the second term of President Theodore Roosevelt, much of which dealt with railroads, ${ }^{22}$ Minnesota enacted measures to curtail railroad rates for merchandise and commodities in 1906. Early in 1907, several railroads filed suit in federal district court in Minnesota, charging that the rates were unlawfully confiscatory, and U.S. Circuit Judge William C. Lochren issued a temporary restraining order. ${ }^{23}$ The railroad industry and the Minnesota legislature then engaged in protracted negotiations, temporarily placing the litigation on a back burner. Those negotiations proved unsuccessful, and indeed, Minnesota passed further measures to regulate passenger rates. The drafters were aware of the Eleventh Amendment jurisprudence and its effect on anticipated litigation by the railroads. The legislation did not charge any state official, including Attorney General Ernest T. Young, with the specific duty of enforcing the law. This was an acknowledged effort to utilize Fitts v. McGhee to prevent the railroads from suing in federal court to obtain injunctive relief. ${ }^{24}$

The strategy failed. In May 1907, the railroads renewed their attacks in federal court, on both Due Process and Commerce Clause grounds, on all of the legislation. The same Judge Lochren heard the case, and in September, he rejected Young's Eleventh Amendment defense and found for the plaintiffs, in part, on the merits. On the jurisdictional issue, he found that there was a contradiction between the demands of the Eleventh and Fourteenth Amendments, and that the former had to give way to the latter in order that the latter be enforceable. ${ }^{25}$ On this reading, he issued an injunction against the state officials. ${ }^{26}$

21. CORTNER, supra note 20, at 137.

22. Id. at 132-33.

23. Id. at 139. The old circuit courts, which were primarily trial courts, continued to function in this period, despite the creation of the circuit courts of appeals in 1891. Congress finally abolished the old Circuit Courts, which dated from the 1789 Judiciary Act, in 1911. FALlON ET AL., supra note 7, at 29, 37 \& n.65; David R. Stras, Why Supreme Court Justices Should Ride Circuit Again, 91 MinN. L. REv. 1710, 1721-26 (2007).

24. CORTNER, supra note 20, at 140-46.

25. Compare the virtually identical reasoning of a unanimous Court in Fitzpatrick v. Bitzer, 427 U.S. 445 (1976), which held that Congressional legislation enacted under the Enforcement Clause of the Fourteenth Amendment could abrogate the states' Eleventh Amendment immunity. But see John Harrison, State Sovereign Immunity and Congress's Enforcement Powers, 2006 SuP. CT. Rev. 353 (concluding on originalist grounds that, contra Fitzpatrick, Congress lacks power to statutorily abrogate the Eleventh Amendment).

26. Cortner, supra note 20 , at 166-67. Judge Lochren's decision, delivered orally, did not 
The judge scheduled further hearings to consider other aspects of the case, which would likely have taken months. Until a final adjudication, the case would not be appealable. This ran counter to Young's desire to quickly appeal the case, as he and his office were confident that the Supreme Court would agree with his Eleventh Amendment defense. To effectuate that strategy, Young defied the federal court injunction by filing an action in state court to enforce the legislation. As he desired, Judge Lochren held him in contempt of court. In October, Young filed an original writ of habeas in the Supreme Court for relief from the contempt. ${ }^{27}$ Oral argument was held in December, and the decision was handed down on March 23, 1908.

Justice Rufus W. Peckham began a long opinion ${ }^{28}$ for the majority with a lengthy summary of the facts, and by portentously acknowledging "the very great importance" of the case "not only to the parties now before the court, but also to the great mass of the citizens of this country." ${ }^{29}$ Initially, the Court described the severe criminal penalties imposed by the statutes for violations, including hefty fines and imprisonment for the railroad's agents. ${ }^{30}$ These provisions, the Court felt, in effect precluded the railroads from pursuing any administrative or judicial remedies. The penalties and the deleterious options for the railroads were so severe that the legislation worked a due process violation, without regard to the question of the alleged insufficiency of the rates themselves. ${ }^{31}$

While the Court alluded to the jurisdictional issue earlier in the opinion, ${ }^{32}$ only after the critique of the penalties did the Court fully engage the Eleventh Amendment issues. In that lengthy part of the opinion, the Court discussed a number of the Eleventh Amendment cases from the prior two decades. The

explicitly discuss or distinguish Fitts or other Eleventh Amendment cases. Perkins v. N. Pac. Ry. Co., 155 F. 445, 446-47 (C.C.D. Minn. 1907).

27. CORTNER, supra note 20, at 170-76. Other states with similar regulatory policies followed the Minnesota litigation with care. Young at one point met with the attorneys general of 15 states to discuss the case, a meeting which led to the creation of the National Association of Attorneys General. Id. at 172-73. Not surprisingly, the NAAG has remained interested in Eleventh Amendment jurisprudence to this day. Michael E. Solimine, Formalism, Pragmatism, and the Conservative Critique of the Eleventh Amendment, 101 Мich. L. Rev. 1463, 1475-79 (2003) (review essay) (noting that large numbers of state attorneys general have filed numerous amicus briefs with the Supreme Court in recent Eleventh Amendment cases).

28. Ex parte Young, 209 U.S. 123, 126-68 (1908). The average Court opinion at this time was considerably shorter. See Walter F. Pratt, Rhetorical Styles on the Fuller Court, 24 Am. J. Legal Hist. 189, 190 n.5 (1980) (average length was 8.9 pages).

29. Young, 209 U.S. at 142.

30. Id. at $145-46$

31. Id. at $147-49$

32. Id. at $143-44$ 
cases that aided Young were distinguished. In re Ayers was brushed aside on the basis that it involved a suit to enforce a contract, and thus was not on point to a suit involving injury to property, as here. ${ }^{33}$ Fitts v. McGhee was distinguished on the grounds that, unlike here, the statute involved did not itself have penalty provisions which discouraged legal challenges, and that in any event the state Attorney General here was generally charged, by common law and other statutes, with enforcing Minnesota law. This was enough, the Court held, to displace reliance on Fitts. ${ }^{34}$

The Court concluded with some general observations regarding the effectuation of constitutional rights in federal court. The result of this suit, it conceded, may be to "draw to the lower Federal courts a great flood of litigation of this character, where one Federal judge would have it in his power to enjoin proceedings by state officials to enforce the legislative acts of the State ....."35 But if this development came to pass, the Court said, it would be neither unprecedented nor unwelcome. Federal courts had for many decades entertained suits challenging state legislation. Moreover, these suits effectuate the "supreme authority" of the U.S. Constitution. "There is nothing in the case before us," the Court concluded, "that ought properly to breed hostility to the customary operation of Federal courts of justice in cases of this character." ${ }^{37}$ The Court denied the habeas writ and dismissed the writ of certiorari, in effect affirming the lower court opinion. ${ }^{38}$

\footnotetext{
33. Id. at $151-53$.

34. Id. at 156-59. The Court also observed that Fitts neither "overruled nor doubted" Smyth v. Ames. Id. at 156 .

35. Id. at 166 .

36. Id. at 167 .

37. Id. at 168 .

38. Id. The dénouement of the Exparte Young litigation is less well known. Upon remand, the scope of the Court's ruling was unclear. Some thought that the entirety of Minnesota's railroad regulatory structure had been declared unlawful; others thought that it was only the penalty provisions of the laws that were enjoined. Eventually the latter view prevailed, and lengthy proceedings in federal court then commenced to adjudicate the plaintiffs' contentions that the rates were unlawfully confiscatory and violated the Commerce Clause. During these proceedings, Judge Lochren retired and Edward Young's term as Attorney General came to end. Young continued to represent the state in the litigation as a special assistant to his successor. In 1910, a special master recommended that all of the railroads' arguments be adopted, and that recommendation was followed in 1911 by the new judge assigned to the case. The case was appealed to the Supreme Court, which unanimously reversed and held for the state in The Minnesota Rate Cases, 230 U.S. 352 (1913). See generally CORTNER, supra note 20, at 199-206. The Court thus handed the railroads "a total defeat after six years of litigation[,]" $i d$. at 206, insofar as it concerned the merits of their contentions. The ability to bring the contentions in federal court in the first instance remained intact. Id.
} 
Justice John M. Harlan was the lone dissenter. The length of his dissent ${ }^{39}$ almost matched that of the majority opinion. Justice Harlan had not been a model of consistency regarding the interpretation of the Eleventh Amendment. He had authored the Court's opinions in Smyth v. Ames and Fitts v. McGhee which, as already noted ${ }^{40}$ sent contradictory signals on whether suing a state official overcame the barrier of the Amendment. Here, he emphasized that Young was sued only because he was an agent of the State of Minnesota, which was tantamount to a suit against the State. ${ }^{41}$ The ability of federal courts to enjoin state actions in these circumstances would, in his view, "work a radical change in our governmental system." ${ }^{42}$ The lower federal courts could "supervise and control the official action of the States as if they were 'dependencies' or provinces." ${ }^{43}$ In contrast, a "decent respect for the states" would remit defendants to raising their federal claims as defenses to enforcement actions in state courts. State courts are obligated to enforce federal law, and their decisions are reviewable in the Supreme Court. ${ }^{44}$ Given those principles, Justice Harlan found it unnecessary to examine in detail the merits of the railroads' attacks on the state officials. He spent considerably more time discussing the Eleventh Amendment jurisprudence. ${ }^{45}$ Cases like In re Ayres and Fitts controlled this one, ${ }^{46}$ he argued, and Smyth v. Ames was distinguishable on the basis that the remedies provided for in that particular state statute in effect waived any sovereign immunity. ${ }^{47}$

39. 209 U.S. at 168-204 (Harlan, J., dissenting).

40. See notes 16-17 and accompanying text supra.

41. 209 U.S. at 174-75 (Harlan, J., dissenting).

42. Id. at 175 .

43. $I d$.

44. Id. at 175-77.

45. Id. at 183 .

46. Id. at 186-93.

47. Id. at 193-95. A recent biography of Harlan discusses a list, prepared by Harlan, of what he regarded as his most important majority and dissenting opinions. Linda PRZYBYSZEWSKI, THE RePubliC According to John Marshall Harlan 147-48 (1999). Perhaps curiously, his Ex parte Young dissent is not on the list, though his Smyth v. Ames opinion is. Id. at 209-11 (reprinting list). Cf. id. at 239 n.63 (describing the Ex parte Young dissent as an "embarrassed about-face" in light of his earlier Eleventh Amendment cases). For his part, Owen Fiss characterizes the dissent as "remarkable" and "one as passionate and yet as lonely as the dissents he filed in the Civil Rights Cases[, 109 U.S. 3 (1883),] and Plessy v. Ferguson[, 163 U.S. 537 (1896)]." FIss, supra note 12, at 215 (footnote omitted). He adds that in his view, Harlan's dissent, with its emphasis on federalism and the limits on the direct access of plaintiffs to the lower federal courts, ran counter to Harlan's support of national rights embodied in the Fourteenth Amendment. Id. at 217-18. Fiss's points deserve more nuanced treatment. Harlan was indeed supportive of the Fourteenth Amendment, but he had complicated views on the powers of the federal government vis-àvis the states. For a fuller discussion, see PrZYByszewski, supra, at 162-84; G. Edward White, John Marshall Harlan I: The Precursor, 19 AM. J. Legal Hist. 1, 5-6, 8 (1975). Limiting direct access to the 
Many years later, Justice William J. Brennan, Jr., described Ex parte Young as the "culmination of efforts by [the] Court to harmonize the principles of the Eleventh Amendment with the effective supremacy of the rights and powers secured elsewhere in the Constitution." ${ }^{48}$ That harmonization came at the cost of doctrinal incoherence. As the Court itself has acknowledged, ${ }^{49}$ along with many commentators, ${ }^{50}$ the decision is fraught with illogic and fiction. By attempting to enforce an unconstitutional law, Young was, according to the Court, "stripped of his official or representative character" for Eleventh Amendment purposes, ${ }^{51}$ yet he is, and must be, a state actor for Fourteenth Amendment purposes. Moreover, the efforts of the majority and of the dissent to synthesize prior Eleventh Amendment cases are hardly convincing. ${ }^{52}$

\section{B. The Reaction to Ex parte Young and the Creation of the Three-Judge District Court}

In an echo of the reaction a century earlier to Chisholm v. Georgia, the Court's decision in Ex parte Young was met with a "storm of controversy." 53

lower federal courts and channeling federal constitutional issues to state courts, both mentioned in the dissent, implicate the modern issue of parity, that is, the competence of state judges to fully and fairly adjudicate federal rights. Critics of parity trace Supreme Court doctrine that is (sometimes) skeptical of parity to the majority opinion in Ex parte Young, among other cases. E.g., Burt Neuborne, The Myth of Parity, 90 Harv. L. REV. 1105, 1108-10 (1977). For further discussion of the modern debate over parity, see Michael E. Solimine, The Future of Parity, 46 WM. \& Mary L. REV. 1457 (2005). part).

48. Perez v. Ledesma, 401 U.S. 82, 106 (1971) (Brennan, J., concurring in part and dissenting in

49. Pennhurst State Sch. \& Hosp. v. Halderman, 465 U.S. 89, 104-05 (1984) (describing Ex parte Young as a necessary fiction).

50. E.g., ER Win Chemerinsky, Federal Jurisdiction 434-46 (5th ed. 2007); JACobs, supra note 10, at 142; Peter W. Low \& John C. JefFries, Jr., Federal Courts and the Law of Federal-State Relations 1021 (6th ed. 2007); Martin H. Redish, Federal Jurisdiction: Tensions in the Allocation of Judicial Power 193-96 (2d ed. 1990); Wright \& Kane, supra note 2, at 311-13; Richard H. Fallon, Jr., The Ideologies of Federal Courts Law, 74 VA. L. REV. 1141, 1195-98 (1988).

51. 209 U.S. at 160 .

52. CURRIE, supra note 12, at 52-54; Leonard, supra note 12, at 269-313. Others have argued that the fictional quality of Ex parte Young has been overstated, since Young was indeed intending to damage the interests of the railroad, and the distinctions drawn in the case have roots in the common law. CHEMERINSKY, supra note 50, at 435. John Harrison has forcefully expanded on this point in his recent article Ex Parte Young, 60 STAN. L. REv. 989 (2008), and "with some help from Charles Alan Wright," further traces the use of the concept of "fiction" to characterize Ex parte Young to scholarly commentary by Kenneth Culp Davis starting in 1958. Id. at 101 n.94.

53. Steffel v. Thompson, 415 U.S. 452, 465 (1974) (quoting Henry M. Hart, JR. \& HerberT Wechsler, The Federal Courts and the Federal System 967 (2d ed. 1973)). For similar characterizations, see Perez v. Ledesma, 401 U.S. 82, 108 (1971) (Brennan, J., concurring in part and 
The existence and category of the storm may seem puzzling. No doubt, the decision broke new doctrinal ground by expanding the exceptions to the Eleventh Amendment. But previous decisions had accomplished much of that work, and prior to 1908 federal district judges were empowered to, and did, issue injunctions against state regulatory legislation in circumstances not dissimilar from those encountered in Ex parte Young. ${ }^{54}$ Despite this arguable continuity, the decision was perceived to be an important break with the past.

Owen Fiss has suggested several explanations for the puzzle. ${ }^{55}$ The most obvious is that Ex parte Young was decided only three years after the notorious Lochner v. New York, ${ }^{56}$ which controversially struck down on Due Process grounds a New York statute regulating the working conditions of bakery employees. ${ }^{57}$ The often-hostile contemporary reaction to Lochner, driven by beliefs that a majority of the Court was imposing its own laissez faire views of economic regulation, generated its own storm of controversy. ${ }^{58}$ It could not have gone unnoticed that Justice Peckham, the author of Ex parte Young, had also written for the majority in Lochner. Coupled with this was the fact that the Progressive Era, and its agenda of limiting the power of courts,

dissenting in part); FISS, supra note 12, at 214; JACOBS, supra note 10, at 146.

54. David P. Currie, The Three-Judge District Court in Constitutional Litigation, 32 U. CHI. L. Rev. 1, 5 (1964). Cf. Swift \& Co. v. Wickham, 382 U.S. 111, 117 (1965) ("'[F]ederal courts of the early nineteenth century had occasionally issued injunctions ... against state officials to prevent the enforcement of state statutes, but such cases were rare and generally of a character that did not offend important state policies."). In her extensive analysis of cases in federal court prior to 1908, where plaintiffs sought various remedies against state action, Ann Woolhandler argues that the relief sought and obtained in Ex parte Young was neither unique nor unprecedented, and that the case "did not fundamentally alter the role of the federal courts so much as [it] gradually changed the [label] under which litigants continued to do what they had done in the past." Ann Woolhandler, The Common Law Origins of Constitutionally Compelled Remedies, 107 YALE L.J. 77, 81 (1997). For a similar analysis of the case, see John A. Ferejohn \& Larry D. Kramer, Independent Judges, Dependent Judiciary: Institutionalizing Judicial Restraint, 77 N.Y.U. L. REv. 962, 1032 n.325 (2002).

55. FISs, supra note 12, at 214-15.

56. 198 U.S. 45 (1905).

57. Id. at 64 .

58. For extensive analysis of the contemporary reaction to Lochner by the Court itself, among legal elites, and among the general public, see Howard Gillman, The Constitution Besieged: The Rise And Demise of Lochner Era Police Powers Jurisprudence 147-205 (1993); Barry Friedman, The History of the Countermajoritarian Difficulty, Part Three: The Lesson of Lochner, 76 N.Y.U. L. REv. 1383 (2001). There is a cottage industry of modern scholarship debating whether Lochner, properly understood, was correctly decided or has stood the test of time. For a small sample of that vast literature, see PAUL KENS, Judicial Power and Reform Politics: The Anatomy of Lochner V. NEW York (1990); Symposium, Lochner Centennial Conference, 85 B.U. L. Rev. 671 (2005); David E. Bernstein, Lochner v. New York: A Centennial Retrospective, 83 WASH. U. L.Q. 1474 (2005). A discussion of that literature is beyond the scope of the present article, as my primary concern is the contemporary effect of Lochner Era jurisprudence in general on the reaction to Ex parte Young. 
was getting well underway in the first decade of the twentieth century. ${ }^{59}$ Finally, the spring of 1908 also saw, coincidentally, a brace of other controversial Supreme Court decisions, and Ex parte Young seemed not to be an isolated event. ${ }^{60}$ Although Ex parte Young had only dealt with Minnesota statutes, at least fourteen other states had implemented similar railroad regulations. ${ }^{61}$

The specter of federal judges enjoining state regulatory legislation had generated proposals in Congress to limit the power of federal courts even prior to Ex parte Young, ${ }^{62}$ but the case reinvigorated those efforts. Various bills were introduced in Congress in 1910 that would have limited the ability of federal judges to issue Ex parte Young-type (i.e., temporary) injunctions, or denied them jurisdiction to do so entirely. ${ }^{63}$ Since some federal judges, before and after the case, had been issuing such injunctions upon ex parte affidavits or on the basis of limited hearings (although Judge Lochren in Ex parte Young itself took no such actions), some bills prohibited the issuance of restraining orders or injunctions before a final hearing. ${ }^{64}$ Other members of Congress were concerned with the perceived affront to states of having a single federal judge enjoin the operation of a state regulatory structure.

The views of Senator Lee Slater Overman of North Carolina ${ }^{65}$ are emblematic of the latter point. In 1908 he introduced legislation requiring that a three-judge district court be convened to hear a case in which plaintiffs sought to enjoin, on constitutional grounds, an official enforcing a state statute. The court would consist of the judge before whom the case was originally filed, plus two other judges, one being a circuit judge. The Chief Judge of each circuit would appoint the additional judges to the court. The

59. See Fiss, supra note 12, at 215; William G. Ross, A Muted Fury: Populists, Progressives, AND LABOR Unions CONFront the COURTS, 1890-1937 (1994).

60. FISS, supra note 12, at 214-15 (referring to Adair v. United States, 208 U.S. 161 (1908) (invalidated federal law barring yellow dog labor contracts); Employers Liabilities Cases, 207 U.S. 463 (1908) (invalidated initial version of Federal Employers Liability Act); Loewe v. Lawlor, 208 U.S. 274 (1908) (applied Sherman Antitrust Act to labor unions)).

61. CORTNER, supra note 20, at 141.

62. Id. at 186 (describing those efforts).

63. Id. at 198; JACOBS, supra note 10, at 146-47; Duker, supra note 4, at 556-57; Joseph C. Hutcheson, Jr., A Case for Three Judges, 47 HARV. L. REV. 795, 803-04 (1934).

64. JACOBS, supra note 10, at 147; Hutcheson, supra note 63, at 800-05.

65. Overman was a Democrat who served in the Senate from 1903 until his death in 1930 and was on the Judiciary Committee for many of those years. 7 Dict. Aм. Biog. 114-15 (1934). He may have been particularly interested in the Ex parte Young litigation, as the Supreme Court decided a companion case from North Carolina the same way. Hunter v. Wood, 209 U.S. 205 (1908). For further discussion of Wood and the reaction in North Carolina to it, see CoRTNER, supra note 20, at 195, 197. 
judges, absent special circumstances, were to hold a hearing before issuing equitable relief, and an appeal of any temporary relief ordered would lie to the Supreme Court. ${ }^{66}$ Specifically referencing ${ }^{67}$ Ex parte Young, Senator Overman lamented the "sad day when one subordinate Federal judge can enjoin the officer of a sovereign State ... there being great feeling among the people of the States by reason of the fact that one Federal judge has tied the hands of a sovereign State. ${ }^{968}$ In his view, three judges rendering a decision would be less likely to face resistance. ${ }^{69}$ Senators Burkett and Nelson added that the other provisions of the legislation would insure that an injunction would issue, if at all, only after all parties had been heard, and that the case would be resolved expeditiously on appeal. ${ }^{70}$ At least one legislator expressed skepticism of the need for such legislation, and noted the potential difficulties of assembling three judges for a trial in the less populated states where the jurists are more dispersed. ${ }^{71}$

Why did the drafters propose this statutory scheme? Some aspects of the proposal are not particularly revolutionary. There are numerous instances of Congress limiting by statute the remedies that federal courts may issue, as opposed to denying those courts of jurisdiction to hear a case. ${ }^{72}$ The path of litigation in Ex parte Young itself had been relatively rapid, despite a full hearing held by the trial judge, and Supreme Court review of the decision had been prompt, despite the absence of a three-judge district court scheme. (To be sure, some of the rapidity was due to Young filing an action in the Supreme Court.) On the other hand, railroad interests had supported the appointment of the trial judge in the case, ${ }^{73}$ so a three-judge court could serve to marginalize such a judge. Though not particularly illustrated by the Young

66. 42 Cong. Rec. 4846 (1908). He pointed out that he had earlier sponsored "more drastic" legislation, which would have prohibited any federal judge from issuing an injunction in Ex parte Younglike circumstances. Id. at 4847. At least one of those proposals had predated the decision. See id. at 4848-49 (describing bill introduced in February of 1908).

67. In addition to referencing Ex parte Young, Senator Overman also mentioned the Hunter case. Id. at 4847 .

68. $I d$.

69. Id.

70. $I d$.

71. Id. at 4851-52 (Senator Heyburn).

72. See FAllon ET AL., supra note 7, at 335-37 (discussing the Norris-LaGuardia Act and other examples of Congress limiting remedies that federal courts could award). Cf. Rockefeller v. Bingaman, 234 Fed. Appx. 852 (10th Cir. 2007) (determining that immunity doctrines barred consideration of the merits of the constitutional attack on Congressional restrictions of the jurisdiction of the three-judge district court in 1976), cert. denied, 128 S. Ct. 619 (2007).

73. CORTNER, supra note 20, at 162. 
litigation, the legislation might be seen as purporting to combat a particular type of injunction: one issued by a judge, often in an ex parte manner, with apparent idiosyncratic views.

Likewise, it might be thought that three minds would come to a better conclusion than just one. In some quarters, there was outrage that one federal judge had the power to strike down state legislation. The source of that discomfort is not clear. After all, a multimember appellate court wielded such power. Perhaps it was thought incongruent or disproportionate for only one subordinate judicial officer to be able to take such an action-overturning the actions of an entire elected legislature signed by a popularly elected governor. ${ }^{74}$ The discomfort has modern echoes. ${ }^{75}$ At any rate, there was precedent for the scheme. Earlier in the decade, Congress had created a three-judge district court to adjudicate certain antitrust and other cases, ${ }^{76}$ and the drafters concerned with Ex parte Young relied on that legislation as a model. ${ }^{77}$ There were also existing provisions for direct appeals to the Supreme Court in certain types of cases. ${ }^{78}$

The Senate passed the bill, ${ }^{79}$ but no further action was taken in the 60th Congress. The matter was taken up again in the next Congress. Once again, Senator Overman led the charge in the Senate, repeating many of the same arguments raised two years earlier. This time, he added that there had been " 150 cases of this kind now where one federal judge has tied the hands of the state officers, the governor, and attorney general," and added that when someone "let[s] one little judge stand against the whole State ... you find the people of the State rising up in rebellion." ${ }^{80}$ The House of Representatives was

74. Currie, supra note 54 , at 6 (referring to the "annoying potential of trial court decisions" issuing injunctions); Hutcheson, supra note 63, at 813 (referring to the "irritation and excitement . . . aroused" by a single judge issuing an injunction). Senator Overman made the point in the text two years later. 45 ConG. REC. 7256 (1910).

75. See, e.g., Coal. for Econ. Equity v. Wilson, 122 F.3d 692, 699 (9th Cir. 1997) (“A system which permits one judge to block with the stroke of a pen what 4,736,180 state residents voted to enact as law tests the integrity of our constitutional democracy."); Dean E. Murphy, Judge in California Voids Ban on SameSex Marriage, N.Y. Times, Mar. 15, 2005, at A12 ("Marriage should not be undermined by the stroke of a pen from a single judge.").

76. Currie, supra note 54, at 7 (explaining that legislation authorized three-judge district courts in 1903 and 1906 for, among other things, antitrust suits brought by the United States and for review of decisions by the Interstate Commerce Commission).

77. 42 Cong. Rec. 4847, 4853 (1908) (Senators Nelson and Bacon).

78. FISs, supra note 12 , at 220 n.122.

79. 42 Cong. ReC. 4859 (1908).

80. 45 Cong. Rec. 7256 (1910). With respect to the 150 cases, Overman referred to Moody's Magazine as a source. A search of the issues of Moody's Magazine published in 1909 and 1910 did not uncover the article to which Overman was apparently referring. Email from Seth Hanft to Professor Michael 
supportive of legislation that would have prevented federal judges from enjoining state legislation at all. ${ }^{81}$ Overman, in contrast, proposed a bill matching his of two years earlier, even though he personally favored the position of the House. ${ }^{82}$ Yet support for legislative restrictions was not universal, either inside or outside of Congress. ${ }^{83}$ In the face of these difficulties, Overman successfully maneuvered to attach his bill as a rider to

Solimine, U. of Cin. C. of L. (July 19, 2007) (on file with author). An analysis of published cases from 1908 to 1910 (which, of course, does not capture litigation that did not result in published opinions) suggests a different story. A search of the Westlaw database of federal cases for that period, for citations to Ex parte Young or for the use of the words "injunction" or "state statutes," yielded thirty cases. Of those, eight granted some form of injunctive relief, while twenty-two did not. (A list of the cases is available from the author). Of course, federal courts could consider issuing injunctive relief without citing Ex parte Young, but it would seem that they would refer to "injunctions." With respect to the actions of "one little judge," Senator Heyburn, who two years earlier had expressed skepticism of the need for the legislation, see supra note 71 and accompanying text, replied that " $[\mathrm{w}] \mathrm{e}$ do not have little judges in our part of the country, and I doubt whether that designation may hardly be applied to any judge." 45 ConG. REC. 7256 (1910). Overman may have been referring to a lower court case from 1907 granting an injunction, after which the governor "publicly urged state officials to ignore it." Swift \& Co. v. Wickham, 382 U.S. 111, 118 n.13 (1965).

81. The House considered such legislation in 1910, both before and after the passage of the MannElkins Act. See Felix Frankfurter \& James M. Landis, The Business of the Supreme Court: A Study in the Federal Judicial System 142-43 (1928). See also Cortner, supra note 20, at 198; Welch Pogue, State Determination of State Law and the Judicial Code, 41 HARv. L. Rev. 623, 625 (1928).

82. 45 Cong. REC. 7256 (1910) (" $[\mathrm{I}] \mathrm{f} \mathrm{I}$ had it in my power I would not allow a federal court to enjoin the enforcement of a state statute.").

83. Within Congress, some members, echoing concerns arising two years earlier, opposed the restrictions put on federal judges, for a variety of procedural and substantive reliefs. Some wondered why injunctions regarding state statutes should be treated any differently from other actions for injunctive relief, while others argued that the legislation was important enough that it should be considered separately, rather than as a rider to other legislation. Id. at 7254-57 (Senators Heyburn and Sutherland). There were skeptical voices outside of Congress as well. E.g., Robert Bruce Scott, The Increased Control of State Activities by the Federal Courts, 3 Am. Pol. Sci. Rev. 347, 361 (1909) ("Over legislation and bad legislation are crying evils of the times. ... Of necessity and of right many acts are thus held unconstitutional and their enforcement prevented."). 
the Mann-Elkins Act, which was concerned with regulation of railroads, ${ }^{84}$ and the three-judge district court was finally enacted into law in June of $1910 .{ }^{85}$

The legislation has been characterized as a "compromise" as a "cosmetic gesture" ${ }^{87}$ for three judges and "largely accepted the Court's activist role" 88 in cases like Ex parte Young. These relatively dismissive evaluations nonetheless seem justified. Despite the harsh criticism of Ex parte Young and similar cases in the two years after the decision, the legislative response was a relatively modest and procedural one. Rather than the full weight of the Progressives bearing down, the response was led by Senators from the south and west-from states with public policies that apparently would be most affected by litigation seeking Ex parte Young-type relief. ${ }^{89}$ It is the type of piece that William Ross has labeled the "muted fury" of the reaction of Progressives to unfavorable decisions by courts. Progressives were particularly critical of Lochner and other decisions contemporaneous with Ex parte Young, ${ }^{90}$ but their efforts to overturn or limit those cases were cautious and ambivalent. Some elements of the Progressive coalition viewed a robust federal judiciary as more supportive of their long-term policy interests than

84. The Senate approved the amendment to the Mann-Elkins Act by a 33-28 vote, with 31 not voting. 45 Cong. Rec. 7257 (1910). The Act dealt with various aspects of the Interstate Commerce Commission, but perhaps is best known for the creation of the Commerce Court, which proved to be a failed experiment and was abolished in 1913. See generally FIss, supra note 12, at 218-19 n.119; JACOBS, supra note 10, at 148; Currie, supra note 54, at 7-8. The three-judge district court statute appears to have been enacted with a whimper, not a bang. Scholarly treatments of the legislative history of the Mann-Elkins Act make no mention of the Overman amendment. See, e.g., Gabriel Kolko, Railroads and Regulation 1877-1916, at 177-95 (1965); George E. Mowry, Theodore Roosevelt and the Progressive Movement 94-102 (1947); 1 Henry F. Pringle, The Life and Times of William Howard TAFT 522-26 (1939). Felix Frankfurter, in his thorough treatment of legislation in this era dealing with federal courts, makes only passing mention of the amendment being part of the Mann-Elkins Act. FRANKFURTER \& LANDIS, supra note 81, at 143.

85. Mann-Elkins Act, H.R. 17536, 61st Cong. § 17 (1910). See Paolo E. Coletta, The Presidency of William Howard TAFT 128 (1973) (discussing easy passage of the final version of the Mann-Elkins Act, with no mention of the three-judge district court provision). The statute, as it pertained to the three-judge district court, was codified at Act of June 19, 1910, § 266, 36 Stat. 1100 and Act of June 25, 1948, ch. 155, § 2281, 62 Stat. 969.

86. CORTNER, supra note 20, at 198; Pogue, supra note 81, at 625.

87. Fiss, supra note 12, at 219.

88. James W. Ely, JR., The Chief Justiceship of Melville W. Fuller, 1888-1910, at 184 (1995).

89. FIss, supra note 12, at 219; Duker, supra note 4, at 556-57; Hutcheson, supra note 63, at 804. Of the 30 published cases from 1908 to 1910 in which Ex parte Young-relief was sought, see supra note 80, 23 were from states in the South and West. See also John B. Gates, Partisan Realignment, Unconstitutional State Policies, and the U.S. Supreme Court, 1837-1964, 31 Aм. J. Pol. Sci. 259, 269-70 (1987) (majority of Supreme Court cases that struck down state statutes were from Democratic-dominated states from the West and South, and Republican and populist-dominated states in the Midwest).

90. Ross, supra note 59, at 43 . 
Congress would be. Many Progressives had a deep respect for American institutions, which put a damper on drastic efforts to curtail federal judicial power. ${ }^{91}$ Conversely, the American Bar Association and other groups desiring to maintain the status quo proved to be formidable opponents to the Progressives. ${ }^{92}$ By the second decade of the century, the Progressives and their allies had a relatively modest set of accomplishments to show for their agitation. ${ }^{93}$

The creation of the three-judge district court fits well in this narrative. There was an initial head of steam in Congress for legislation, which would have all but overruled Ex parte Young, but the efforts abated from one Congress to another. Congressional opponents of the Progressive agenda were supportive of the decision, though they appeared to couch their support in procedural and institutional terms. Indeed, the eventual legislative compromise reached was grounded largely in procedure, and can only be regarded as a modest rebuke to the Court. There was little evidence that three federal judges, rather than just one, would consistently be less likely to award injunctive relief, and the direct appeal would hurry the case to the Court that decided Ex parte Young. Perhaps it is surprising that the legislation passed at all. The passage seems to be due to a confluence of favorable circumstances, such as the convenience of the contemporary passage of the Mann-Elkins Act and the fact that, according to Overman, the U.S. Attorney General, many governors and state attorneys general, and even many original opponents of anti-Ex parte Young legislation, supported the compromise. ${ }^{94}$ In these circumstances, the Congressional action responding to Ex parte Young was modest indeed.

91. Id. at $15,58-60$.

92. For excellent overviews of the views and actions of contending interest groups in this time period, see Friedman, supra note 58; Edward Hartnett, Why Is the Supreme Court of the United States Protecting State Judges from Popular Democracy?, 75 TEx. L. REv. 907, 933-56 (1997).

93. Ross, supra note 59, at 69 (discussing, among other things, the Mann-Elkins Act and other Congressional legislation which responded to Court decisions adverse to the Progressive agenda).

94. 45 CONG. REC. 7253, 7256 (1910) (describing support for the legislation); id. at 7254 (stating that in hearings on the legislation, while representatives of railroads and manufacturers "opposed ... any legislation upon this subject, they were entirely satisfied with the provisions of this amendment.") (Sen. Overman). 


\section{The Rise of Ex Parte YounG and the Fall of the Three-Judge District COURT}

\section{A. The Ascendancy of Ex parte Young}

Whether or not Ex parte Young, properly understood, broke significant new doctrinal ground, ${ }^{95}$ there is little doubt that the case was perceived in many quarters as doing so. Edward Purcell exemplifies the standard view when he argues that the case "reshaped federal law" in no less than "four distinct areas." "96 It not only (1) established an exception to Eleventh Amendment immunity, but also (2) "in effect" created a new cause of action for injunctive relief, one not authorized directly by any federal statute. Purcell continues that Ex parte Young (3) established that Fourteenth Amendment claims were cognizable in federal court without a claim that state actors were committing independent legal wrongs, and (4) permitted circumvention of the "well-pleaded complaint rule," which holds that ordinarily a federal legal issue must be part of a plaintiff's cause of action, as opposed to an anticipated defense, to be within the parameters of the federal courts' "arising under" jurisdiction. ${ }^{97}$

Perhaps taken aback by the perception, and by the Chisholm-esque storm of controversy, the Court spent the remainder of the century clipping the wings of Ex parte Young. ${ }^{98}$ In the same year, the Court held that, as matter of

95. See supra notes 51-53 and accompanying text.

96. Edward A. Purcell, Jr., Brandeis and the Progressive Constitution: ERIE, the Judicial Power, and the Politics of the Federal Courts in Twentieth-Century America 42 (2000). For a different view, arguing that Ex parte Young was not doctrinally revolutionary, see Harrison, supra note 52, at 996 (the case presents "no exception, no fiction, no new cause of action, and no paradox").

97. PurCelL, supra note 96, at 42-43. For further discussion of the doctrinal significance of the case as described in the text, see Low \& JefFries, supra note 50, at 1028; James E. Pfander, Principles of Federal Jurisdiction 186-88 (2006). As Purcell points out, Purcell, supra note 96, at $43 \mathrm{n} .25$, the Court established the well-pleaded complaint rule, interpreting the general federal question statute, now codified at 28 U.S.C. § 1331, in earlier cases, e.g., Tennessee v. Union and Planters' Bank, 152 U.S. 454 (1894) (Peckham, J.), and has applied it to the present day. Interestingly, the case most cited for that proposition, Louisville \& Nashville R.R. Co. v. Mottley, 211 U.S. 149 (1908), was decided only eight months after Ex parte Young was rendered, and does not cite the latter case. For a thorough discussion of Union and Planter's Bank and other cases that developed the well-pleaded complaint rule, see Collins, supra note 11, at $730-60$.

98. Legal elites sympathetic to the Progressive critique of the Lochner Era Court did not abandon efforts to limit the impact of cases from that Court, even if the fury was generally limited. Henry Friendly, later a highly distinguished federal judge on the 2d Circuit, reported that Ex parte Young was "the bête noire of liberals in [my] law school days." Henry J. Friendly, Federal JuRisdiction: A General View 3 n.7 (1973). Friendly graduated from Harvard Law School in 1927. 
comity, the sort of injunctive relief authorized by the case was not ordinarily available until litigants had exhausted state legislative or administrative remedies. ${ }^{99}$ In later decades, the Court established abstention doctrines, which in various circumstances required federal courts to abstain from hearing cases when the federal legal issues could be mooted by the resolution of state law issues that could be decided by state courts ${ }^{100}$ or adjudicated themselves in state court proceedings, such as criminal proceeding brought against the federal court plaintiff. ${ }^{101}$ The Court also held that Ex parte Young only applied to a request for prospective, injunctive relief, not to the retrospective damages relief that would likely be paid for by the State. In the latter circumstance, the exception would fall away, and the Eleventh Amendment would bar relief. ${ }^{102}$ Finally, the Court recently held that Ex parte Young-type relief would not be available when Congress created a statutory remedial scheme, which would be undermined if immediate injunctive relief were available. ${ }^{103}$ On the other

99. Prentis v. Atlantic Coast Line Co., 211 U.S. 210 (1908). The significance of this holding was considerably blunted by decisions, decades later, holding that there was no such exhaustion requirement for causes of action brought under 42 U.S.C. $\S 1983$, which modern litigants would typically use. E.g., Patsy v. Fla. Board of Regents, 457 U.S. 496 (1982). See generally WRIGHT \& KANE, supra note 2, at 316-17.

100. The leading case here is Railroad Commission of Texas v. Pullman Co., 312 U.S. 496 (1941). While there were abstention-type cases decided before Pullman, the Court itself has traced the doctrinal lineage of all of the abstention doctrines back to Pullman. See Zwicker v. Koota, 389 U.S. 241, 248 (1967). Significantly, Justice Frankfurter authored the unanimous opinion in Pullman, and prior to his appointment to the Court in 1939, he was an influential Harvard Law School professor with a considerable body of scholarly work on the federal courts, e.g., FRANKFUR TER \& LANDIS, supra note 81. He was sympathetic to Progressive ideas, and authored numerous books and articles generally calling for a restrained view of the exercise of federal judicial equity authority. See, e.g., Felix Frankfurter, Distribution of Judicial Power Between United States and State Courts, 13 CoRNELL L.Q. 499, 517-20 (1928) (acknowledging the holding of Ex parte Young but also arguing that generally state courts should in the first instance hear the issues in such "sensitive" cases, and describing with apparent approval the creation of the three-judge district court). For discussion of Frankfurter's views on these and related matters, see Mary B. McManamon, Felix Frankfurter: The Architect of "Our Federalism," 27 GA. L. Rev. 697 (1993); Wallace Mendelson, Mr. Justice Frankfurter on the Distribution of Judicial Power in the United States, 2 MidweST J. Pol. SCI. 40 (1958); Edward A. Purcell, Jr., Reconsidering the Frankfurterian Paradigm: Reflections on Histories of the Lower Federal Courts, 24 LAW \& Soc. InQuiRy 679 (1999). See also Note, Federal-Question Abstention: Justice Frankfurter's Doctrine in an Activist Era, 80 HARV. L. Rev. 604, 605 n.12 (1967) (tracing abstention doctrines to "a judicial uneasiness with the doctrine of Ex parte Young").

101. E.g., Younger v. Harris, 401 U.S. 37 (1971). A full summary and discussion of the abstention doctrines is beyond the scope of the present article. See generally FALLON ET AL., supra note 7, at 1186-1283; WRIGHT \& KANE, supra note 2, at 324-52.

102. E.g., Edelman v. Jordan, 415 U.S. 651 (1974).

103. Seminole Tribe of Fla. v. Florida, 517 U.S. 44, $73-76$ (1996). 
hand, the Court has rejected (or ignored) efforts to overrule Ex parte Young ${ }^{104}$ or impose still further doctrinal restrictions on the holding. ${ }^{105}$

Even in a minimalist garb, Ex parte Young proved to be a significant engine of legal change in the twentieth century. Plaintiffs in civil rights cases in federal court in the 1950s and 1960s aggressively sought injunctive relief premised on Ex parte Young and its progeny. ${ }^{106}$ It seems only a small exaggeration to suggest that "the entire class of modern civil rights litigation would be excluded from the federal courts" absent the Ex parte Young exception to Eleventh Amendment jurisprudence. ${ }^{107}$ Otherwise, federal constitutional rights could still be litigated but often only as actions against arms (or officials) of a State in state court, or as defenses to coercive actions by state officials in those courts. While the importance of the case is usually framed in the context of the modern Civil Rights era, ${ }^{108}$ the legal community earlier in the century also understood its usefulness to federal court plaintiffs challenging all kinds of state regulatory actions. ${ }^{109}$

104. Ray v. Atlantic Richfield Co., 435 U.S. 151, 156 n.6 (1978) (declining to overrule Ex parte Young). Some writers have argued, explicitly or implicitly, that Ex parte Young should be overruled on the basis that it is an unprincipled exception to the Eleventh Amendment immunity, e.g., U.S. DePartment of Justice, Office of Legal Policy, Report to the Attorney General: Justice Without Law: A Reconsideration of the "Broad Equitable Powers" of the Federal Courts 84-85 (1988), and Leonard, supra note 12, at 269-314, but this is clearly a minority position. Some amici in recent Eleventh Amendment cases call for Ex parte Young to be overruled. See Solimine, supra note 27, at 1473 n.58 (giving examples).

105. In 1997 Justice Kennedy and Chief Justice Rehnquist suggested that Exparte Young-type relief should only be granted on "case-by-case" basis, and that lower courts should "reflect a sensitivity" to other factors, such as the nature and significance of the federal right at issue, the state interests implicated, and the availability of a state forum. State v. Coeur d'Alene Tribe of Idaho, 521 U.S. 261, 270-76 (1997) (Kennedy, J., joined on this point by Rehnquist, C.J.). He argued that all requests for injunctive relief in federal court should be informed by equity and comity concerns, $i d$. at 278-80, so that the Young "exception [to the Eleventh Amendment would] reflect a proper understanding of its role in our federal system and respect for state courts, instead of a reflexive reliance on an obvious fiction." Id. at 270. But other Justices declined to join the call for a "vague balancing case" to apply Ex parte Young, id. at 296 (O'Connor, J., joined by Scalia \& Thomas, JJ.), and in later cases the Court declined to follow Justice Kennedy's suggested approach. See Verizon Md. v. Pub. Serv. Comm'n, 535 U.S. 635, 645 (2002) (Scalia, J.). So charmed is the doctrinal life of Ex parte Young that Justices of all jurisprudential stripes have come to its defense. The same might be said of academics. E.g., Jesse H. Choper \& John C. Yoo, Who's Afraid of the Eleventh Amendment: The Limited Impact of the Court's Sovereign Immunity Rulings, 106 CoLUm. L. Rev. 213, 225-32 (2006) (discussing continued vitality of Ex parte Young).

106. Fiss, supra note 4, at 3-5; Herbert Hovenkamp, Judicial Restraint and Constitutional Federalism: The Supreme Court's Lopez and Seminole Tribe Decisions, 96 Colum. L. Rev. 2213, 2246 (1996).

107. JEFFRIES, supra note 4 , at 7.

108. Id.; Wright \& Kane, supra note 2, at 314; Owen M. Fiss, Dombrowski, 86 Yale L.J. 1103, 1148-49 (1977).

109. Hutcheson, supra note 63, at 799 n.9 ("The authority and finality of Exparte Young can hardly 
The injunctive power that Ex parte Young bestowed on federal courts apparently gave pause to at least some members of the Court over the past century. Likewise, the decision was a convenient and conspicuous target for Congressional critics of federal courts. It is largely for those reasons that for "half a century Congress and the Court vied in placing restrictions on the doctrine . . . announced" in Ex parte Young. ${ }^{110}$ That period began with the establishment of the three-judge district court in 1910. Congress increased the jurisdictional ambit of the court several times in the ensuing decades, a topic taken up in the next section of this article. For the moment, it is worth noting that Congress also enacted two-Depression Era limits on the authority of federal judges to issue injunctions. The Johnson Act of $1934^{111}$ deprived district courts of jurisdiction to enjoin orders of state administrative boards affecting rates for a public utility. The Tax Injunction Act of $1937^{112}$ prohibited a federal court from issuing an injunction against the collection of state taxes if an adequate remedy was available under state law.

be overestimated.") (published in 1934 by a judge on the U.S. Court of Appeals for the Fifth Circuit).

110. WRIGHT \& KANE, supra note 2, at 314.

111. Act of May 14, 1934, ch. 283, 48 Stat. 775 (codified at 28 U.S.C. $\S 1342$ ). See generally WRIGHT ET AL., supra note $3, \S 4236$. The Johnson Act was passed 26 years after Ex parte Young, and the delay is explained in part by the growth in the interim of the size and influence of local utilities, which in turn led to their regulation by states and challenges to such regulation in federal courts. Comment, Limitation of Lower Federal Court Jurisdiction Over Public Utility Rate Cases, 44 YALE L.J. 119, 121 (1934). In 1928 Frankfurter suggested that "[p]robably no type of litigation gives rise to more conflict between state authorities and the federal courts than the tendency of lower federal courts to enjoin state regulation of local utilities." Frankfurter, supra note 100, at 519.

112. Act of Aug. 21, 1937, ch. 726,50 Stat. 738 (codified at 28 U.S.C. $\S 1341$ ). The impetus for the 1937 Act was largely the same as that for the 1934 Act, see WRIGHT ET AL., supra note 3, § 4237, at 241, and was driven in part by efforts by businesses to use federal court litigation "to delay or avoid paying state taxes." State v. Grace Brethren Church, 457 U.S. 393, 409 n.22 (1982). For a careful examination of the legislative history of the 1937 Act, concluding that a response to Ex parte Young was the primary but not sole factor in its passage, see Frederick C. Lowinger, Note, The Tax Injunction Act and Suits for Monetary Relief, 46 U. Chi. L. Rev. 736, 739-44 (1979). Another statute passed in this era, the Declaratory Judgment Act of 1934, 48 Stat. 955 , was meant to deal with problems raised by injunctive actions filed in three-judge district courts. As the Court later explained, the granting of such relief- "even by these courts of special dignity - 'rather clumsily' crippled state enforcement of its statutes pending further review." Steffel v. Thompson, 415 U.S. 452, 466 (1974). Congress "intended declaratory relief to act as an alternative to the strong medicine of the injunction." Id. But see id. at 478 (Rehnquist, J., concurring) (the Act's legislative history "suggests that its primary purpose was to enable persons to obtain a definition of their rights before an actual injury had occurred, rather than to palliate any controversy arising from Ex parte Young"). 
B. Congress Tinkers with the Three-Judge District Court, 1913-1937

While these other statutes limited the application of Ex parte Young, Congress was not through with the three-judge district court. Some of the changes were minor. In 1913, Congress amended the statute to include suits seeking injunction of orders of state administrative boards. ${ }^{13}$ A more substantial change took place in the next decade. The 1910 statute had been restricted to suits where temporary injunctive relief was sought; whether to grant permanent injunctive relief would still fall to one district judge. This distinction was anomalous, since the rationale for the existence of a three-judge district court did not sharply implicate different types of injunctive relief, and in theory, the one district judge might deny relief when the three judges earlier might have granted it (or vice-versa). The anomaly was corrected in 1925 when Congress amended the statute to include requests for permanent injunctive relief as well. ${ }^{114}$ The provision was tucked into the Judges' Bill, which famously provided that, in response to concerns over rising caseloads, most of the Supreme Court's appellate jurisdiction would no longer be mandatory, but rather would be governed by the discretionary writ of certiorari. ${ }^{115}$

In this light, the amendment to the three-judge district court statute might seem odd; it expanded the potential number of automatic appeals (by expanding the jurisdiction of the three-judge district court) while eliminating most other such appeals. Indeed, one might think that the Bill's drafters would have eliminated the direct appeal provision of the 1910 statute or, perhaps, even considered abolishing the three-judge district court as a whole. Such drastic medicine was apparently not even considered. ${ }^{116}$ Perhaps it was due to

113. Act of March 4, 1913, ch. 160, 37 Stat. 1013. The Court later opined that the amendment was likely unnecessary, since the 1910 statute already covered the situation. Okla. Natural Gas Co. v. Russell, 261 U.S. 290, 292 (1923). The 1913 amendment also provided that a three-judge district court should stay any federal court proceedings, if a state court had stayed proceedings under state law, pending adjudication of issues in state court. The provision saw little use and came to be regarded as a "dead letter," WRIGHT ET AL., supra note 3, at $\S 4243$, at 363 (footnote omitted), since the statutory abstention provision was narrowly construed. See Pogue, supra note 81.

114. Act of February 13, 1925, ch. $229, \S 238$, 43 Stat. 936, 938. For discussions of the anomaly, see Currie, supra note 54 , at 8 ; Hutcheson, supra note 63 , at 821 .

115. For general discussion of the passage and provisions of the Judges' Bill, see FranKFURTER \& LANDIS, supra note 81, at 256-94; Edward A. Hartnett, Questioning Certiorari: Some Reflections SeventyFive Years After the Judges' Bill, 100 Colum. L. Rev. 1643 (2000).

116. Former President William Howard Taft was the most vigorous proponent of what became the Judges' Bill, both before and after his appointment as Chief Justice in 1921. See Justin Crowe, The Forging of Judicial Autonomy: Political Entrepreneurship and the Reforms of William Howard Taft, 69 J. PoL. 73 
a perception that there would be relatively few such appeals from three-judge district courts, and hence that they would not burden the Court like other automatic appeals. ${ }^{117}$ Moreover, the burden, such as it was, was apparently tolerable as the three-judge district courts were only hearing those federal constitutional issues that were perceived to be more important than the issues raised in a typical case that might end up before the Court. ${ }^{118}$

Congress expanded the coverage of the three-judge district court again in 1937. In that year, the statute was amended to include constitutional attacks on Congressional legislation. ${ }^{119}$ The amendment was a relatively minor remnant of President Roosevelt's storied Court-packing plan, which of course was driven in large part by the Court striking down various federal statutes passed during the New Deal. ${ }^{120}$ While the discussion of the amendment in Congress paled in comparison to the rest of FDR's plan, ${ }^{121}$ what attention it

(2007); Hartnett, supra note 115, at 1660-1704. In his voluminous writings in support of the eventual legislation, he made only passing mention of the three-judge district court and its direct appeal provisions, and did not argue that those provisions should be changed. E.g., William Howard Taft, Possible and Needed Reforms in Administration of Justice in Federal Courts, 8 A.B.A. J. 601, 602 (1922). After passage of the Bill, he took a slightly different tack, suggesting that appeals from such courts should be by certiorari, rather than by obligatory appeals. William Howard Taft, The Jurisdiction of the Supreme Court Under the Act of February 13, 1925, 35 YALE L.J. 1, 6 (1925). "[B]ut," he added, "their special governmental or public importance prevailed to make them exceptions." Id. For his part, Frankfurter, in his extensive analysis of the passage of the Judges' Bill, only refers in passing to the "minor" change found in the Bill to the three-judge district court. FRANKFURTER \& LANDIS, supra note 81, at 278.

117. Frankfurter reported that from the 1913 through 1926 Terms, 108 cases involving Ex parte Young-type injunctions were appealed to the Supreme Court. Frankfurter, supra note 100, at 518. This is an average of about seven appeals per Term, which does not seem an excessive burden.

118. See Ex parte Collins, 277 U.S. 565, 569 (1928) (Brandeis, J., for a unanimous Court) (briefly discussing the 1925 Act and appeals from three-judge district courts). Cf. William H. Taft, The Attacks on the Courts and Legal Procedure, 5 Ky. L.J. 3, 15, 18 (Oct. 1916) (arguing that obligatory appeals are appropriate in certain constitutional cases). Perhaps the lack of attention to modifying the three-judge district court was also due, in part, to the apparent desire of the Taft Court to take an aggressive approach toward review of some state administrative decisions, some of which took place via the three-judge district court. David E. Lilienthal, The Federal Courts and State Regulation of Public Utilities, 43 HARV. L. Rev. 379 (1930); Robert Post, Federalism in the Taft Court Era: Can It Be "Revived"?, 51 Duke L.J. 1513, 1550-52 (2002). See generally Ann Woolhandler \& Michael G. Collins, Judicial Federalism and the Administrative States, 87 CAL. L. REV. 613, 635-50 (1999) (discussing interaction of three-judge district courts and abstention doctrines in federal court review of state administrative decisions).

119. Act of Aug. 24, 1937, ch. 754,50 Stat. 752 (codified at 28 U.S.C. $\S 2282$ ).

120. WRIGHT ET AL., supra note $3, \S 4243$ at 600 . The literature on the Court-packing plan is voluminous. For overviews, see Keith E. Whittington, Political Foundations of Judicial Supremacy: The Presidency, the Supreme Court, and Constitutional Leadership in U.S. History 61-64, 266-70 (2007); Laura Kalman, The Constitution, the Supreme Court, and the New Deal, 110 Aм. Hist. Rev. 1052 (2005).

121. David Currie may overstate the point when he says there was "little discussion" of the amendment in Congress. Currie, supra note 54, at $11 \mathrm{n} .60$. The amendment was the subject of a lengthy 
received was due to the perception that litigation attacking Acts of Congress should be of "equal dignity" to suits attacking state statutes, and should receive the perceived benefits of rapidity of disposition and greater deliberation provided by the court. ${ }^{122}$ The amendment seems largely to have been a face-saving afterthought, passed in the wake of the demise of the far more controversial provisions of the Court-packing plan. ${ }^{123}$

\section{The Three-Judge District Court and the Civil Rights Movement}

After the statutory modification in 1937, Congress essentially left the three-judge court statute alone for three decades. ${ }^{124}$ As of the 1948 codification of the Judicial Code, the principal statutes provided that a three-judge district court should be convened when a plaintiff sought injunctive relief against the enforcement of a state ${ }^{125}$ or federal ${ }^{126}$ statute on the basis that the statute was unconstitutional. A direct appeal from the decision of that court was available to the Supreme Court. ${ }^{127}$ The major changes to these statutes in the 1970s can only be understood in light of the

committee report and some discussion on the floor of Congress. See Comment, The Three-Judge Federal Court in Constitutional Litigation, 27 U. CHI. L. Rev. 555, 561-63 (1960).

122. Currie, supra note 54, at 11 (discussing legislative history of the 1937 amendment and quoting Senator Mahoney). The 1937 amendment also provided that the federal government could intervene in private litigation that challenged the constitutionality of Congressional statutes. See, e.g., Carter v. Carter Coal Co., 298 U.S. 238 (1936) (private suit striking down Bituminous Coal Conservation Act on Commerce Clause grounds). According to one source, the clamor for that provision exceeded that for the three-judge district court to adjudicate such cases. Comment, The Three-Judge Court Act of 1910: Purpose, Procedure, and Alternatives, 62 J. Crim. L., Criminology \& Police SCI. 205, 206 n.9 (1971) [hereinafter Comment, The Three-Judge Court Act of 1910].

123. See William G. Ross, The Chief Justiceship of Charles Evans Hughes, 1930-1941, at 133 (2007). Almost all of the modern literature on the plan makes only passing mention, if at all, of the amendment. E.g., Leonard BAKer, Back to Back: The Duel between FDR AND THe Supreme Court 266-67 (1967). This appears to be true of contemporary commentary as well. E.g., JosEPH ALSOP \& Turner Catledge, The 168 Days 224 (1938) (suggesting that passage of the amendment was part of a deal eventually brokered between supporters and opponents of the plan).

124. As recounted below, Congress made certain actions under the Civil Rights Act of 1964 and the Voting Rights Act of 1965 that were subject to litigation before a three-judge district court. It would be another decade still before Congress revisited the primary three-judge district court statute. See infra Part III. D.

125. 28 U.S.C. $\S 2281$ (2006). In the recodification, Congress amended the provision regarding state statutes to apply to requests for all injunctions, whether or not preliminary relief was sought. 62 Stat. 968 (1948); Reviser's note to $\S 2281$. This conformed to the 1937 statute regarding challenges to federal statutes.

126. 28 U.S.C. $\$ 2282(2006)$.

127. 28 U.S.C. $\S 1253(2006)$. 
significant and underappreciated role the institution of the three-judge district court played during the Civil Rights Era.

During these decades, there was a significant amount of litigation before three-judge district courts. In the 1950 s, there were about fifty such cases each year, which steadily increased to about ninety each year during the early 1960 s, to 215 in 1969 , and to a high of 320 by $1973 .{ }^{128}$ Of course, not all of these cases were challenges to state practices usually associated with desegregation litigation and related aspects of the civil rights movement. Significant cases on other issues litigated during the Warren Court and the first half of the Burger Court had their genesis in three-judge district courts. ${ }^{129}$ However, considerable anecdotal and empirical evidence demonstrates that three-judge district courts, and the prospect of convening such courts, played a particularly significant role in civil rights litigation.

The chroniclers of the storied litigation campaign of the NAACP and the NAACP Legal Defense Fund (LDF) ${ }^{130}$ to desegregate schools and other public institutions after World War II have discussed the role of the three-judge district court. At the early stages of that campaign, Thurgood Marshall and his colleagues were aware that some of the litigation they pursued at the trial level

128. For data on the 1950s and 1960s, drawn from the Annual Reports of the Administrative Office of the United States Courts, see Am. Law Inst., Study of the Division Between State and Federal CourTs 317-18 (1969) [hereinafter ALI Study]. For data from 1964 to 1994, drawn from the same sources, see Michael E. Solimine, The Three-Judge District Court in Voting Rights Litigation, 30 U. MicH. J.L. REFORM 79, 137 tbl.1 (1996).

129. For the Warren Court, see, for example, the stream of reapportionment litigation after Baker $v$. Carr, 369 U.S. 186 (1962), rev'g, 179 F. Supp. 824 (M.D. Tenn. 1959) (per curiam) (three-judge court), most of which were appeals from three-judge district court decisions. Peyton McCrary, Bringing Equality to Power: How the Federal Courts Transformed the Electoral Structure of Southern Politics, 5 U. PA. J. Const. L. 665, 668-89 (2003) (discussing reapportionment and other election law cases); Solimine, supra note 128, at 105. For the Burger Court, see, for example, Roe v. Wade, 410 U.S. 113 (1973) (abortion regulation), aff'g 314 F. Supp. 1217 (N.D. Tex. 1970) (per curiam) (three-judge court); San Antonio Independent School District v. Rodriguez, 411 U.S. 1 (1973) (school finance), rev'g 337 F. Supp. 280 (W.D. Tex. 1971) (per curiam) (three-judge court); and Craig v. Boren, 429 U.S. 190 (1976) (gender discrimination), rev'g 399 F. Supp. 1304 (W.D. Okla. 1975) (three-judge court). For other examples, see Solimine, supra note 128, at 105-06. Just as there were efforts by plaintiffs in the Civil Rights era to litigate cases before three-judge district courts, as discussed below, later cases were marked by such forum shopping. See, e.g., Paul A. Sracic, San Antonio v. Rodriguez and the Pursuit of Equal Protection: The Debate over Discrimination and School Funding 36-37 (Peter Charles Hoffer \& N.E.H. Hull eds., 2006) (discussing pros and cons considered by plaintiff's lawyers in litigating case before three-judge district court).

130. The NAACP and NAACP LDF were and are separate entities, but in what follows, I treat them as more or less interchangeable, since they appear to have had the same position on the role of the threejudge district court. For a discussion of the cooperation and later conflict between the organizations, see Stephen L. Wasby, Race Relations Litigation in an Age of Complexity 316-29 (Kermit Hall \& David O'Brien eds., 1995). 
would come before such courts since state statutes, not merely local practices or the actions of individual officials, would be attacked. Thus, Brown v. Board of Education ${ }^{131}$ and other well-known education cases $^{132}$ of this era were litigated before such courts. As a general matter, the plaintiffs' litigation teams wanted the cases to be before such courts because it negated the prospect of a single, possibly unsympathetic, judge hearing the case, and because three judges were more likely to take the bolder legal steps, on both the merits and remedies, that the cases demanded. ${ }^{133}$ The three-judge district court route was also favored because it provided for a direct, more expeditious route to the Supreme Court, bypassing the U.S. Court of Appeals and at least putatively requiring the Supreme Court to hear the case on the merits. ${ }^{134}$ The use of Ex parte Young to present claims in federal court is evident: the state court option was clearly disfavored and rarely voluntarily used by either prospective plaintiffs or defendants. ${ }^{135}$

131. 98 F. Supp. 797 (D. Kan. 1951) (three-judge court), rev'd, 347 U.S. 483 (1954).

132. E.g., Briggs v. Elliot, 98 F. Supp. 529 (E.D.S.C. 1951) (three-judge court) (school desegregation), rev'd, 347 U.S. 483 (1954); McLaurin v. Okla. Bd. of Regents, 87 F. Supp. 526 (W.D. Okla. 1949) (three-judge court) (college desegregation), rev'd, 339 U.S. 637 (1950).

133. Jack Greenberg, Crusaders in the Courts: How a Dedicated Band of Lawyers Fought for the Civil Rights Revolution 69-70 (1994); J.W. Peltason, Fifty-Eight Lonely Men: Southern Federal Judges And School Desegregation 108-09 (rev. ed. 1970); MARK V. Tushnet, Making Civil Rights Law: Thurgood Marshall and the Supreme Court, 1936-1961, at 156 (1994); Robert J. Steamer, The Role of the Federal District Courts in the Segregation Controversy, 22 J. PoL. 417, 424 (1960). Cf. Fiss, supra note 4, at 28 n.35 (noting that a three-judge district court can depersonalize a reference to a single judge issuing an injunction).

134. TUSHNET, supra note 133, at 156; WASBY, supra note 130, at 128; Steamer, supra note 133. Many such appeals have been and are summarily affirmed or reversed, without an accompanying opinion. Other such appeals are set for oral argument and further briefing and are decided by a written opinion. In both instances, the resolution by the Court is technically on the merits. Even the summary dispositions are entitled to some precedential weight, though the Court has never been clear how much. EUGENE GRESSMAN et AL., Supreme Court Practice 304-10 (9th ed. 2007); Jonathan L. Entin, Insubstantial Questions and Federal Jurisdiction: A Footnote to the Term-Limits Debate, 2 NEv. L.J. 608, 613-17 (2002); Solimine, supra note 128 , at 108-09.

135. The scorecard of the NAACP LDF before state courts in this period was a mixed and mostly negative bag. See, e.g., Sweatt v. Painter, 210 S.W.2d 442 (Tex. 1948), rev'd, 339 U.S. 629 (1950) (law school desegregation); Commonwealth v. Morgan, 34 S.E.2d 491 (Va. 1944), rev'd, 328 U.S. 373 (1946) (Virginia statute segregating buses violates Interstate Commerce Clause). LDF lawyers prevailed in one notable state court case, combined with others on appeal to the Supreme Court in the Brown litigation, that desegregated schools in Delaware. Gebhart v. Belton, 91 A.2d 137 (Del. 1952), aff'd, 347 U.S. 483 (1954). Yet even in that case, plaintiffs had initially filed in federal court, which abstained in deference to state court proceedings, an action the plaintiffs did not contest once a sympathetic judge (Collins Seitz, who later served on the U.S. Court of Appeals) was assigned to the state trial court. GREENBERG, supra note 133, at 135-36. During much of the Civil Rights Era, it was an article of faith that, at least in the South, many or most state court judges were indifferent or hostile to the enforcement of federal rights. MICHAL R. BELKNAP, Federal Law and Southern Order: Racial Violence and Constitutional Conflict in the Post- 
The three-judge district court was not always a perfect fit for the civil rights plaintiffs. The danger was that the plaintiffs might favor the single district judge to whom the case was originally assigned and would not want two other judges to be added. For example, in Briggs $v$. Elliott which involved the desegregation of public schools in South Carolina and was litigated parallel to the other cases that also made up Brown, Marshall would have been happy to litigate before the original district judge J. Waties Waring, whom he regarded as favorable to his cause. ${ }^{136}$ The likely new judges were considered less favorable, and the plaintiffs considered structuring the litigation in such a way to prevent a three-judge court from being convened. ${ }^{137}$ In due course, a three-judge court was convened, and that court eventually held for the defendants, with Judge Waring dissenting. ${ }^{138}$ Although other three-judge district courts also held for the defendants in the early stages of the litigation campaign, the Supreme Court, as occurred in Briggs, reversed the decisions. ${ }^{139}$

However, on the whole, after Brown civil rights litigators perceived the three-judge district court as being favorable to their cause, especially in the Deep South. During the Civil Rights Era, major cases were decided before

Brown South 120-21 (1987); Michael J. Klarman, From Jim Crow to Civil Rights: The Supreme Court and the Struggle for Racial Equality 459-60 (2004). For further discussion of references on this point, with the suggestion that much of the literature too quickly conflates the hostility or indifference of the southern state law enforcement apparatus with state judges as such, see MichaEL E. Solimine \& James L. Walker, Respecting State Courts: The Inevitability of Judicial Federalism 36-37 (1999). 2004).

136. Greenberg, supra note 133, at 121-22; Richard Kluger, Simple Justice 294-303 (rev. ed.

137. Requesting injunctive relief against a state practice automatically called for the convening of a three-judge district court. Plaintiffs might be able to avoid that path by seeking more modest relief: by not challenging segregative practices as such, but only requesting that unequal facilities be made equal. There was a fine line between these strategies, and the cost of the narrower one was that it blunted the point of the suit in the first instance. KLARMAN, supra note 135, at 460-61; KLUGER, supra note 136, at 302; TUSHNET, supra note 133, at 156. For those reasons, it appears that during this era most civil rights plaintiffs, even when faced with a choice, rarely engaged in strategies to avoid the convening of a threejudge district court. E.g., GREENBERG, supra note 133, at 126-27 (discussing the strategic choice in the Brown litigation, and noting that the complaint was drafted so a three-judge court would be convened). For some rare counter-examples, see Stephen L. WASBy et AL., DeSEgregation From BRowNto ALEXANDER 301-02 (1977) (discussing Turner v. City of Memphis, 199 F. Supp. 585 (W.D. Tenn. 1961) (three-judge court), vacated, 369 U.S. 350 (1962) (per curiam), in which an African-American plaintiff in a sit-in case sought to move for summary judgment before a single judge, while the defendants sought the convening of a three-judge district court); Robert Jerome Glennon, The Role of Law in the Civil Rights Movement: The Montgomery Bus Boycott, 1955-1957, 9 LAW \& Hist. REV. 59, 69-70 (1991) (noting that one of the federal court cases filed early in the Montgomery Bus boycott was before a single district judge because only damages, not injunctive relief, were sought).

138. See supra note 132.

139. See cases cited supra notes 131-32 (Brown and McLaurin litigation). 
three-judge district courts, due no doubt to plaintiffs routinely seeking the convening of such courts. ${ }^{140}$ Not surprisingly, defendants, depending on the circumstances, sometimes resisted these efforts and sought to keep the case before a single district judge. ${ }^{141}$ Indeed, federal judges themselves were not oblivious to these strategies, and sometimes they apparently maneuvered to keep other federal judges, those unsympathetic to plaintiffs, off three-judge court panels. For example, in the late 1950s and early 1960s, the Chief Judges of the Fifth Circuit, through various means, limited or blocked the assignment of Circuit Judge Ben Cameron and District Judge Harold Cox of Mississippi to three-judge district courts to which they were likely to have been added. ${ }^{142}$

Narratives of Civil Rights Era litigation give credit to the three-judge district court, but the evidence is somewhat anecdotal in nature. ${ }^{143}$ Although this evidence tells us something, recall that there were scores of such cases heard each year during this period. Was the three-judge district court, as compared to single district judges, more favorable to civil rights plaintiffs overall? Several empirical studies suggest that the answer is yes. Two studies by Eleanor Main and Thomas Walker examined large numbers of published district opinions from 1963 through 1968 to compare decisions on civil

140. E.g., Bush v. Orleans Parish Sch. Bd., 190 F. Supp. 861, 463 (E.D. La. 1960) (three-judge court), aff'd, 366 U.S. 212 (1961) (one of many cases, see WASBY ET AL., supra note 137, at 195 (adjudicating challenges to Louisiana statutes passed in the wake of Brown)); Browder v. Gayle, $142 \mathrm{~F}$. Supp. 707, 709 (M.D. Ala.) (three-judge court), aff'd, 352 U.S. 903 (1956) (Montgomery Bus boycott); Lee v. Macon County Bd. of Educ., 267 F. Supp. 458, 460 (M.D. Ala.) (three-judge court) (Johnson, J.), aff'd, 389 U.S. 215 (1967) (invalidating measures meant to prevent desegregation of Alabama schools during governorship of George Wallace).

141. Steamer, supra note 133, at 425 (citing cases where a three-judge district court was sought but denied).

142. Judges Cameron and Cox openly opposed legal efforts to implement Brown. In sharp contrast, Elbert Tuttle, the Chief Judge of the Fifth Circuit from 1960 to 1967, had progressive views on implementing Brown, and there is persuasive evidence that he sought to "pack" three-judge district court panels (and panels on the Fifth Circuit) by keeping Cameron and Cox off such panels. Based on normal rules of random assignment of judges, Cameron and Cox would have been appointed to some of those panels. There is a considerable literature on this episode. See, e.g., JACK BASS, UnLikely Heroes 231-47 (1981); Deborah J. Barrow \& Thomas G. Walker, A Court Divided: The Fifth Circuit Court of Appeals and the Politics of Judicial Reform 38-44, 55-60 (1988); J. Robert Brown, Jr. \& Allison Herren Lee, Neutral Assignment of Judges at the Court of Appeals, 78 Tex. L. REv. 1037, 1044-65 (2000); Jonathan L. Entin, The Sign of "The Four": Judicial Assignment and the Rule of Law, 68 Miss. L.J. 369 (1998); Solimine, supra note 128, at 110-12; Comment, Judicial Performance in the Fifth Circuit, 73 Y ALE L.J. 90 (1963). In another episode, Judge Cameron complained in an appellate dissent that a three-judge district court should have been convened when it was not. JoHn M. SPIVACK, RaCE, Civil RightS AND THE United States Court of Appeals for the Fifth Judicial Circuit 105 (1990).

143. E.g., BASs, supra note 142, at 19 (three-judge district courts "played a significant role in the [civil rights] period"). 
liberties issues by single district judges and three-judge district courts. ${ }^{144}$ They hypothesized that judges in the latter, collegial setting would be more likely to lead to the upsetting of the status quo by finding that a statute violates constitutional guarantees. ${ }^{145}$ In both instances, they found the hypothesis confirmed at statistically significant levels. ${ }^{146}$ One of the studies also examined the voting behavior of eleven district judges who sat in both settings, and it found that nine of them were more likely to vote to strike down statutes when sitting in a three-judge court. ${ }^{147}$

Another study by Francine Sanders did not purport to examine these courts comparatively, but her results are similar to those of Main and Walker. Sanders examined how federal district courts decided cases regarding desegregation of various public facilities, both before and after Brown. ${ }^{148}$ She compiled 110 published district court opinions decided from 1944 through 1964 raising Brown-type issues and found, among other things, that the plaintiffs' rate of success was 33\% before Brown and $72 \%$ after Brown. ${ }^{149}$ She mentioned that three-judge district courts are in her data set, but she did not further investigate the effect of that variable. ${ }^{150}$ My examination of her data set reveals that about $20 \%$ were three-judge district court decisions. ${ }^{151}$ Although plaintiffs in her study enjoyed particular success as a whole after Brown was decided in 1954, their rate of success in three-judge district court cases was even higher, approaching $90 \% .{ }^{152}$

144. Eleanor C. Main \& Thomas G. Walker, Choice Shifts and Extreme Behavior: Judicial Review in the Federal Courts, 91 J. Soc. Psychol. 215, 220 (1973) (521 cases); Thomas G. Walker \& Eleanor C. Main, Choice Shifts in Political Decisionmaking: Federal Judges and Civil Liberties Cases, 3 J. ApPLIED Soc. Psychol. 39, 42 (1973) (1,995 cases).

145. Main \& Walker, supra note 144, at 219; Walker \& Main, supra note 144, at 43.

146. Main \& Walker, supra note 144 (individual judges struck down statutes in $45 \%$ of cases, while three-judge district courts struck down statutes in 67\%); Walker \& Main, supra note 144, at 43 (analogous figures were $30 \%$ and $65 \%$ ).

147. Walker \& Main, supra note 144 , at $44-45$.

148. Francine Sanders, Brown v. Board of Education: An Empirical Reexamination of Its Effects on Federal District Courts, 29 Law \& Soc'y Rev. 731, 731 (1995).

149. Id. at $740-43$.

150. Id. at 745 .

151. Id. at 748-56 (appendix of cases).

152. For the entire time period, plaintiffs prevailed in $65 \%$ of the cases and the success rates before single judges and three-judge district courts were $63 \%$ and $68 \%$, respectively. For cases decided from 1955 through 1964, the success rates for the two types of courts were $75 \%$ and $90 \%$, respectively. (All computations are derived from the cases listed in the Sanders article.) In a later study based on what appears to be a very similar data set, Sanders does examine the influence of the three-judge district court. David W. Romero \& Francine Sanders Romero, Precedent, Parity, and Racial Discrimination: A Federal/State Comparison of the Impact of Brown v. Board of Education, 37 LAw \& Soc'y REv. 809, 814-15 (2003). She found that three-judge district courts were more likely to find for plaintiffs, as compared to single 
A final study by Calvin Montgomery Miller examined characteristics of three-judge district court decisions in the decade before the 1976 amendment. ${ }^{153}$ Innovatively covering both published and unpublished cases, he focused on 320 cases decided in the Fourth and Fifth Circuits from 1963 through 1975 since those years were the focal points in that era of civil rights litigation brought by minority plaintiffs. ${ }^{154} \mathrm{He}$ found that at the trial level plaintiffs prevailed on the merits in $45 \%$ of the cases, defendants prevailed in $35 \%$, and the remainder were disposed of on other grounds. In contrast, 99 of the cases were appealed to the Supreme Court and plaintiffs prevailed in $77 \%$ of those appeals. ${ }^{155}$ This rate of success, he concluded, compared favorably with similar cases litigated before single district judges in the same circuits and time periods. ${ }^{156}$

These empirical studies by their nature do not capture the full flavor and nuances of the litigation before three-judge district courts during the Civil Rights Era. They do not purport to examine the universe of three-judge court cases decided during this period. Nor does the binary variable of plaintiffs' winning or losing convey the often-complex nature of the factual and legal decisions brought before these courts. But they do suggest that the anecdotal accounts of the plaintiffs' bar in high-profile civil rights cases had a basis in fact and indeed extended beyond the cases brought by the NAACP and its affiliated groups and lawyers.

Congress was not entirely oblivious to the opportunities three-judge district court litigation presented during the Civil Rights Era. As part of the Civil Rights Act of 1964, Congress included provisions which permitted the

judges, though not at a statistically significant level. Id. at 821 .

153. Calvin Montgomery Miller, The Impact of the Abolition of Three-Judge District Courts on Minority Litigants' Access to the Federal Courts (1977) (unpublished Ph.D. dissertation, Lehigh University) (on file with author).

154. Id. at 28-38 (describing data collection and focus on decisions in the two circuits). In addition to collecting cases officially published in the Federal Supplement, Miller examined records maintained by the Administrative Office of the U.S. Courts in various U.S. District Courts. Id. at 33. Of the 320 cases, $56 \%$ were published. $I d$. at 82 .

155. Id. at 82,89 .

156. $I d$. at 103-04 (comparing results with more general studies of race relation litigation in federal courts during the same time period). Miller correctly observes that the comparisons must be made with caution, since the factual and legal issues raised in non-three-judge court cases are not identical to those in other cases. Id. at 104. Miller compared his data to the work of Kenneth Vines, whose studies of the voting behavior of federal district judges in the Deep South concluded that some of those judges were influenced by their background and connections with local political culture. Those differences correlated to various degrees with rulings in favor of African-American litigants. E.g., Kenneth N. Vines, Federal District Judges and Race Relation Cases in the South, 26 J. PoL. 337, 356-57 (1964). Vines, however, does not mention or study the actions of three-judge district courts. 
Attorney General to request the convening of a three-judge district court to adjudicate whether injunctive relief is necessary to enforce certain provisions prohibiting discrimination in voting rights, public accommodations, or employment. ${ }^{157}$ Congress provided for these courts because of the asserted need to expedite appeals of such cases, as well as due to a candid assessment that some district judges, acting alone, had not upheld federal civil rights even when the facts were compelling. ${ }^{158}$

More substantial and controversial were analogous provisions in the Voting Rights Act of 1965. The Act prohibited a variety of practices that affect or impair the ability to vote in state elections. Section 5 of the Act provided that certain states or parts of states, mainly in the Deep South, which had historically raised barriers to the voting rights of African-Americans, would need to pre-clear certain changes to voting procedures with the Attorney General, or file a declaratory judgment before a three-judge district court in the District of Columbia. Any appeal of the latter decision would go directly to the Supreme Court. ${ }^{159}$ It is not entirely clear why the judicial preclearance option was vested in the federal court in the District of Columbia, much less a three-judge district court. Part of the explanation lies in venue requirements, which at the time required that federal officials (the nominal defendants in a preclearance suit) be sued only in the nation's capital. There was also some support for creating in effect a specialized federal court to deal with these matters, to lead to greater uniformity in interpreting the Act, and perhaps to ensure that preclearance actions would not be litigated before parochial federal judges. ${ }^{160}$ Finally, echoing the legislative response 55 years

157. 42 U.S.C. $\S 1971$ (g) (voting rights), § 2000a-5(b) (public accommodations), § 2000a-6(b) (employment).

158. H.R. ReP. No. 88-914 (1964), reprinted in 1964 U.S.C.C.A.N. 2391, 2391 (referring to the need for "expeditious determination" in these cases); $i d$. at 2394 (referring to the problem of "often unwarranted delays"); id. at 2490-91 (additional views of Rep. McCulloch et al.) (arguing that single judges "have in some instances refused to act in the face of convincing evidence," and that the "balance and broad range of views" of three judges "should assure fewer instances of delay and a greater willingness to safeguard the individual's right to vote"). Opponents of these provisions were not oblivious to the policy rationales. Id. at 2464 (separate minority views of Reps. Poff and Cramer) (vesting of discretion in the Attorney General to call for a three-judge district court enables him, "when he has no confidence in the individual district judge involved, to do a little forum shopping") (emphasis in original). For a good overview of the legislative history of these provisions, see William F. Atkin, Comment, A Return to Normalcy: Should Three-Judge District Courts in the 1964 and 1965 Civil Rights Acts Be Eliminated?, 1974 ARIZ. ST. L.J. 321, 330-32.

159. 42 U.S.C. $\S \S 1973$ b-c. For further commentary on the preclearance provisions of the 1965 Act, see Samuel Issacharoff et al., The Law of Democracy: Legal Structure of the Political Process 459-526 (3d ed. 2007); Peyton McCrary et al., The End of Preclearance As We Know It: How the Supreme Court Transformed Section 5 of the Voting Rights Act, 11 МicH. J. RACE \& L. 275 (2006).

160. See J. Morgan Kousser, The Strange, Ironic Career of Section 5 of the Voting Rights Act, 
earlier to Ex parte Young, the sensitive federalism concerns raised by the intrusion of the Act on traditionally state-regulated practices called for the presumed dignity of the three-judge court. ${ }^{161}$

Congress's use of a three-judge district court in the Voting Rights Act exemplified the ironies that attended the court in the Civil Rights Era. The most obvious was that the NAACP lawyers saw the court largely as a tool in their favor, enabling them to marginalize unsympathetic federal judges in the South. Simultaneously, they were aggressively utilizing the direct ticket to federal court issued by Ex parte Young. These tactics would no doubt have surprised the members of Congress who passed the 1910 statute, for they viewed it as a check on both plaintiffs who were attacking state statutes and the federal judges who would hear such challenges. By the same token, it does appear that Southern officials who were defendants in these suits were not particularly cowed by the decisions of three-judge courts, as opposed to those of single district judges. Some decisions were challenged, and some not, but it did not appear to depend on the type of tribunal that issued the decision. ${ }^{162}$

1965-2007, 86 Tex. L. Rev. 667, 681 (2008) (noting that the "safely nonsouthern District Court of the District of Columbia was slated to be the principal venue for vetting new southern election laws"). The point was not lost on the Congressional opponents of this aspect of the Voting Rights Act, one of whom provocatively referred to states in the South and elsewhere as needing to "prostrate [themselves] before a three-judge Federal court in a foreign jurisdiction and establish [their] innocence." ABIGAIL THERNSTROM, Whose Votes Count? Affirmative Action and Minority Voting Rights 19-20 (1987) (emphasis added) (quoting Rep. Tuck (Va.)). Other opponents considered the provision as insulting to federal judges outside of the District of Columbia. Id. at 20. Alexander Bickel argued that another reason Congress designated the federal court in the District of Columbia was to provide a presumably favorable forum for an expected constitutional challenge to the Act. Alexander M. Bickel, The Voting Rights Cases, 1966 SuP. Ст. Rev. 79, 79. As it happens, the Supreme Court upheld the Act in a case brought within its original jurisdiction, bypassing the three-judge district court. See State v. Katzenbach, 383 U.S. 301 (1965). The Court held, among other things, that Congress was within its constitutional powers to limit preclearance actions to a federal court in the District of Columbia. Id. at 331. Yet another advantage that the D.C. Circuit possessed was that the appointment process for its judges was not subject to the typical senatorial courtesy. There are no Senators from the District to whom deference must be afforded. This was illustrated by the career of J. Skelly Wright. After he issued some controversial opinions ordering school desegregation while a U.S. District Judge in Louisiana (including those in which he was a member of a three-judge district court, see supra note 142), his appointment to the Fifth Circuit was blocked by conservative Democrats. The Kennedy Administration then appointed him to the D.C. Circuit when a vacancy occurred on that court. BASS, supra note 142, at 155-57. Judge Wright later opposed the complete abolishment of the three-judge district court. See infra note $204 \&$ accompanying text.

161. For further discussion on the intent of the drafters of this aspect of the preclearance provisions, see Brian K. Landsberg, Free at Last: The Alabama Origins of the 1965 Voting Rights Act 180-82 (2007); Thernstrom, supra note 160, at 16-21; Michael E. Solimine, Institutional Process, Agenda Setting, and the Development of Election Law on the Supreme Court, 68 Онго Sт. L.J. 767, 784 n.76 (2007).

162. Solimine, supra note 128, at 105-06. See also Miller, supra note 153, at 82-83 (in a study of 320 
Congress itself in the 1960s came to have quite different views of the utility of the court than the Congress of a half-century earlier. By giving new business to three-judge districts in the 1964 Civil Rights Act, Congress was reflecting the litigation strategy of the civil rights plaintiffs bar. Likewise, the extension of the court to hear preclearance actions under the 1965 Voting Rights Act, exclusively in the nation's capital no less, largely aligned the views of Congress with those who would litigate actions to enforce new statutory voting rights. This too departed from the original purpose of the three-judge court, which was a shield, if only a partial one, for the states. By the 1960s, Congress was utilizing the three-judge district court as a sword.

\section{Congress Downsizes the Three-Judge District Court}

Little more than a decade after adding more business to the docket of three-district courts, Congress seriously considered abolishing the court, and ended up significantly restricting the types of cases that are litigated before the courts. To understand why Congress dramatically changed its stance towards the court requires a consideration of the views of the Supreme Court and other institutional actors were involved in the reconsideration in the 1970s.

First, consider the Supreme Court. In the first years of the life of the three-judge district court, the Justices had not expressed, to Congress or otherwise, any particular opposition to, or support of, the creation or extension of the institution. ${ }^{163}$ As more direct appeals from courts came before the Court, that stance eroded. As early as 1928 , the Court unanimously held that the statute, despite its "generality," was only meant to cover a "limited class of cases of special importance," and that Congress "realized ... it was imposing 
a severe burden upon the federal courts" by requiring that three judges, including at least one appellate judge, be convened in a trial court. ${ }^{164}$ Similarly, in 1941, the Court declared, again unanimously, that the statute was not "a measure of broad policy to be construed with great liberality, but as an enactment technical in the strict sense of the term and to be applied as such." ${ }^{165}$ And almost from the beginning, the Court construed the direct appeal statute to permit it to dispose of cases summarily without oral argument or a written explanatory opinion, in a manner similar to the denial of a writ of certiorari. ${ }^{166}$

To be sure, as David Currie has observed, the three-judge court statute was "long-winded, repetitive, and sloppy in draftsmanship." 167 The poor draftsmanship required the Court to confront a series of complicated, interrelated questions of interpretation, including the circumstances (i.e., the nature of the suit and the relief that was sought) that required the court to be convened, whether that issue was waivable or immediately appealable, and what would follow if a three-judge district court was improperly convened. A full discussion of the Court's resolution of these issues is beyond the scope of this article. ${ }^{168}$ Suffice it to say that in almost every instance, the Court reached a conclusion that made it easier for lower court judges to avoid convening the court or for the Court itself to dispose of appeals from such courts with minimal effort on its part. ${ }^{169}$ As the Court later stated, its "interpretation of the

164. Ex parte Collins, 277 U.S. 565, 567-69 (1928) (Brandeis, J.).

165. Phillips v. United States, 312 U.S. 246, 251 (1941) (Frankfurter, J.). This language was frequently quoted in later Court cases, which narrowly construed the statute. WRIGHT ET AL., supra note $3, \S 4234$, at 602 . Some scholars have questioned whether this statement accurately reflects Congressional intent regarding the mandatory appeal statute. See, e.g., Mark Tushnet, The Mandatory Jurisdiction of the Supreme Court-Some Recent Developments, 46 U. CIN. L. Rev. 347, 350 (1977). Prior to his joining the Court, Frankfurter had seemed agnostic or favorable towards the three-judge district court, see supra note 100, but as his authorship of Phillips demonstrates, he came to generally oppose use of the court. Currie, supra note 54 , at 58 . If there was a change in his views, it may have been due to a realization that the purported benefits of the court, as a limit on federal court interference with social legislation, were outweighed by the administrative burdens it placed on the federal court system.

166. Gressman ET AL., supra note 134, at 298-304; Hartnett, supra note 115, at 1708-10; Solimine, supra note 128, at 104-07. Cf. supra note 134 (discussing how summary dispositions of appeals from threejudge district courts are considered on the merits).

167. Currie, supra note 54, at 12. See also Gonzalez v. Automatic Employees Credit Union, 419 U.S. 90, 96-97 (1974) (referring to the "very awkwardly worded" statutes that constitute three-judge district courts).

168. The definitive discussion of the Court's encounters with these issues is in Currie, supra note 54. See also WRIGHT ET AL., supra note 3, $\S 4234$ at 601 (referring to the "great confusion" of these issues and their complexity, which was "virtually beyond belief.") (footnote omitted). For further examples, see the many cases summarized in Gonzalez, 419 U.S. at 96 n.14.

169. The definitive account of these cases up to 1964 is in Currie, supra note 54, at 14 (no 
three-judge court statutes [had] frequently deviated from the path of literalism." $" 170$ It is often observed that the Court construes ambiguous jurisdictional statutes in different ways for different eras, depending on whether federal court intervention is thought to be necessary. ${ }^{171}$ Much of the federal court doctrine developing in the 1950s and 1960s can be said to reflect the notion that at least some state courts were not up to the task of fully and fairly adjudicating federal rights. ${ }^{172}$ The limiting constructions the Court gave in the Civil Rights Era to the three-judge district court statutes can be seen as consistent with that general rule. This is not to say that, absent the three-judge district court, such actions would have been litigated in state courts, but that the Court's actions here limited the reach of a federal statute intended to curb the powers of the federal judiciary.

The incongruity of that path with the embrace of the three-judge district court by much of the civil rights plaintiffs bar is striking. It might seem particularly surprising since the Warren Court, not to mention many lower federal court judges, was perceived as a venue generally sympathetic to the aspirations of the civil rights movement. What accounts for the diversion of views? ${ }^{173}$ The Justices may have thought it unseemly to require that

application to request for declaratory relief); $i d$. at 30 (no application to attacks on legislative actions of political subdivisions); $i d$. at 37 (no application to attacks on administrative or executive action); $i d$. at 64-65 (no application if the state statute is "clearly unconstitutional"). For a discussion of such cases decided after 1964, see Sidney B. Jacoby, Recent Proposals and Legislative Efforts to Limit Three-Judge Court Jurisdiction, 26 CASE W. Res. L. Rev. 32, 43 (1975); Peter T. Joseph, Note, Judicial Limitation of Three-Judge Court Jurisdiction, 85 YALE L.J. 564 (1976).

170. Gonzalez, 419 U.S. at 96 (footnote omitted).

171. E.g., Richard H. Fallon, Jr., The "Conservative" Paths of the Rehnquist Court's Federalism Decisions, 69 U. CHI. L. Rev. 429, 465 (2002) ("federal courts have long assumed . . . a 'principled discretion' in 'fine tuning' open-ended jurisdictional grants"); Richard H. Fallon \& Daniel J. Meltzer, Habeas Corpus Jurisdiction, Substantive Rights, and the War on Terror, 120 HARv. L. Rev. 2029, 2042 (2007) (referring to the "accordion-like" expansion and contraction of the statutes providing for habeas review of state court convictions). See generally Barry Friedman, A Different Dialogue: The Supreme Court, Congress, and Federal Jurisdiction, 85 Nw. U. L. Rev. 1 (1990); David L. Shapiro, Jurisdiction and Discretion, 60 N.Y.U. L. REv. 543 (1985).

172. Ann Althouse, Tapping the State Court Resource, 44 VAND. L. Rev. 953, 957 (1991); Robert Jerome Glennon, The Jurisdictional Legacy of the Civil Rights Movement, 61 Tenn. L. REv. 869, 876-79 (1994).

173. This is not to say that the views always diverged. An example of where the Court's desire to limit litigation before the three-judge court converged with plaintiffs' desire not to convene a three-judge court is Bailey v. Patterson, 369 U.S. 31 (1962) (per curiam). In Bailey, the Freedom Riders of Mississippi sought to enjoin enforcement of state travel segregation statutes. Id. Even though, in plaintiffs' minds, the unconstitutionality of those statutes was well established by that point, a three-judge court was convened, and in a 2-1 decision the court abstained from issuing an injunction, pending further proceedings in state courts. 199 F. Supp. 595 (S.D. Miss. 1961) (three-judge court). With the support of an amicus brief from the Department of Justice, the plaintiffs appealed and the Supreme Court reversed, holding that the issue 
three-judge district courts be convened in a larger number of cases at a time when some plaintiffs' litigation strategies were predicated on labeling some individual federal district judges as recalcitrant. What likely played a larger role were institutional concerns - the systematic burden and individual inconvenience to judges to assemble and serve on such courts - coupled with the many direct appeals to the Supreme Court itself. As late as the 1960 Term, the Court decided only nine such appeals with full opinions; during the rest of the 1960s, the Court was deciding twenty to thirty, or more, of such appeals with opinion. ${ }^{174}$

Scholarly commentary at the time was more explicit about calling into question the need for three-judge district courts. In a particularly influential article, David Currie argued that "consuming the energies of three judges to conduct one trial is prima facie an egregious waste of resources," and that the direct appeal provision was an unnecessary variance with the rest of the Supreme Court's discretionary docket. ${ }^{175}$ If a three-judge court was appropriate at all, he suggested, it should be limited to "[r]ace-relations and reapportionment cases [, which] have caused a good deal of friction between the states and the courts." 176 Other scholarly commentary was almost uniformly critical of the three-judge district court for similar reasons and called for limiting its jurisdiction or its abolition. ${ }^{177}$

on the merits was settled and "foreclosed as a litigable issue" and that a three-judge court need not be convened when the constitutional issue was "frivolous." The case was remanded for further proceedings before a single judge. 369 U.S. at 33-34. For further background on the case, see BASS, supra note 142, at 223; GREenBerG, supra note 133, at 564; WASBY, supra note 130, at 270-71. Cf. Gonzalez, 419 U.S. at 96 n.14 (citing Bailey as an example of a non-literal interpretation of the statute, presumably because the statute does not differentiate between different types of constitutional challenges); Currie, supra note 54, at 65 ("The punishment of the language of section 2281 [in Bailey] is considerable, but the result makes sense in light of three-judge policy."); WRIGHT ET AL., supra note 3, at 617-18 (“Although the reasoning of Bailey is shaky, its result is salutary.") (footnote omitted).

174. Solimine, supra note 128 , at 138 tbl.2.

175. Currie, supra note 54 , at 2,74 .

176. Id. at 75 .

177. E.g., Comment, supra note 121, at 571 (arguing for abolition); Comment, The Three-Judge Court Act of 1910, supra note 122, at 217-19 (arguing for revision or abolition); Note, The Three-Judge Court Reassessed: Changing Roles in Federal-State Relationships, 72 YALE L.J. 1646, 1660 (1963) (arguing that only racial segregation and reapportionment cases should go before a three-judge district court; given the controversy raised by such cases, it is more "appropriate because of its greater dignity and ability to elicit a compliant response") (footnote omitted); Note, The Three-Judge District Court: Scope and Procedure Under Section 2281, 77 HARV. L. REv. 299, 302-03 (acknowledging burdens and arguable anachronism created by the court, but arguing that it is still appropriate in certain cases, such as those involving racial discrimination, reapportionment, and religion in schools). 
In a similar fashion, the American Law Institute (ALI) in 1969 issued its long-planned study on various aspects of federal jurisdiction. ${ }^{178}$ The study proposed various statutory amendments, which would resolve many of the uncertainties regarding the application of the statute. ${ }^{179}$ On the central point of the need for the court at all, the study proposed that the court be convened when an independent statute required it, or when there was a constitutional attack on a state (but not a federal) statute, and a defendant requested a three-judge district court. ${ }^{180}$ In the accompanying commentary, the drafters of the study drew on the considerable critical discussion on, and the Supreme Court opinions interpreting, the court. ${ }^{181}$ The study canvassed the now familiar reasons that were advanced in the prior decade to restrict the court's jurisdiction or abolish it entirely. These included the increasing number of hearings convened before such courts and the resulting increase of direct appeals to the Supreme Court. The study argued that the 1937 extension to challenges to federal statutes should be rescinded, since there were no issues of federalism in such challenges and since other safeguards were in place to provide a swift resolution of such cases. ${ }^{182}$

In contrast, the study argued that the three-judge district court should stay in place to hear challenges to state legislation. The circumstances that surrounded the creation of the court in 1910 no longer applied. Equity Rules adopted by the Supreme Court in 1912 had placed limits on the ex parte granting of injunctive relief, while the "image of the federal courts as a barrier against liberal state legislation [had] long since disappeared." ${ }^{183}$ But "other controversies" had arisen which led to "strained relations" between federal courts and states. ${ }^{184}$ No exemplary list was provided, but the reference to cases under the Fourteenth Amendment's Equal Protection Clause implicated race relation and reapportionment cases, among others. In such cases, the "moral authority of a federal court order is likely to be maximized if the result cannot

178. ALI Study, supra note 128. Chief Justice Warren had asked the ALI in 1959 to conduct such a study. Id. at ix. For discussion of the study, placing it in context of other studies done of the federal courts in the 1970s and 1980s, see Thomas E. Baker, Rationing Justice on Appeal: The Problems of the U.S. Courts of APPEALS 33-34 (1994); Wright \& Kane, supra note 2, at 22-23.

179. ALI STUdy, supra note 128, at 48-56.

180. Id. at 53 .

181. Id. at $318-23$

182. Id. at 325 . The report observed, among other things, that at the time, by a separate statute, direct appeals to the Supreme Court were available from district court decisions holding a Congressional statute unconstitutional. Id. (citing 28 U.S.C. § 1252 (repealed 1988)).

183. Id. at 319.

184. Id. 
be laid to the prejudices or political ambitions of a single district judge." 185 Further line drawing about cases implicating "important" state policies was difficult, so the study rested with the notion that the reference to attacks on statewide statutes should be retained. ${ }^{186}$

The ALI study was the opening salvo in an increasingly public campaign in the early 1970s to restrict or abolish the three-judge court. Much of the impetus for the barrage can be credited to Chief Justice Warren Burger, who assumed his post in 1969. More so than his predecessor, he brought to his office a desire to increase administrative efficiencies of all sorts at all levels of the federal courts. ${ }^{187}$ The institution of the three-judge district court did not escape his attention. Citing the ALI study but expressly going beyond it, he called for the abolition of the court. ${ }^{188} \mathrm{He}$ appointed a committee of distinguished academics and judges, chaired by Harvard law professor Paul Freund, to report on various proposals to manage the Supreme Court's increasingly heavy caseload. ${ }^{189}$ In 1972 that committee recommended, among other things, that the general three-judge district court be abolished. ${ }^{190}$ At the same time, the Judicial Conference of the United States, the lobbying arm of the federal judiciary, endorsed the abolition of the court. ${ }^{191}$ It cannot escape notice that much of the jurisprudence of the early Burger Court placed increasing restrictions on the access of litigants to federal courts, ${ }^{192}$ and the Chief Justice's efforts to abolish the three-judge district court can be seen as

185. Id. at 320 (footnote omitted).

186. $I d$. For further discussion of the report's recommendations on three-judge district courts, see Jacoby, supra note 169, at 34-37.

187. See Carl Tobias, Warren Burger and the Administration of Justice, 41 VILL. L. REV. 505 (1996).

188. Warren E. Burger, The State of the Federal Judiciary—1972, 58 A.B.A. J. 1049, 1053 (1972). See also Miller, supra note 153, at 44-45 (giving further examples of Burger's calls for abolishing the threejudge district court).

189. Federal Judicial Center, Report of the Study Group on the Caseload of the Supreme Court, 57 F.R.D. 573, 596-99 (1972) [hereinafter Freund Report]. Cf. Gerhard Casper \& Richard A. Posner, A Study of the Supreme Court's Caseload, 3 J. Legal Stud. 339, 370 (1974) (suggesting that the Freund Report's recommendations to abolish the three-judge district court and its direct appeals were "relatively uncontroversial," and given the Court's use of summary dispositions of such appeals, that the reform would be more of a ratification of the existing practice than a change in it). For discussion of the other recommendations of the Freund Report and their fate, see ChEMERINSKY, supra note 50, at 662-64. 190. $I d$.

191. Reports of the Proceedings of the Judicial Conference of the United States 78-79 (1970).

192. Miller, supra note 153, at 22-24 (giving various examples of Burger Court decisions restricting standing, the use of class actions, and the availability of remedies in civil rights cases). See also Arthur D. Hellman, Deciding Who Decides: Understanding the Realities of Judicial Reform, 15 LAW \& SOC. INQUIRY 343, 353-54 (1990) (book review) (noting that contemporary critics of the Freund Report linked its recommendations to the presumed ideological agenda of Burger). 
a piece of a broader agenda to limit the injunctive powers previously exercised by federal district courts, especially in civil rights and structural litigation. ${ }^{193}$

The Court's own opinions called into question the need for the three-judge court. Perhaps the most dramatic example was Justice Potter Stewart's opinion for a unanimous court in 1974 in Gonzalez v. Automatic Employees Credit Union. ${ }^{194}$ There, the Court made a relatively minor addition to three-judge court doctrine by holding that when such a court denies relief on the ground that the plaintiff lacked standing, the court should have dissolved itself, with an appeal of the standing issue brought in the first instance in the U.S. Court of Appeals. It also continued the long-standing practice of expressly construing the statute narrowly to minimize "the mandatory docket of this Court in the interests of sound judicial administration." ${ }^{195}$ In this regard, the Court observed that direct appeals from three-judge district courts were an exception to the normal process of the U.S. Courts of Appeals screening cases before they reached the certiorari stage, and hindered the percolation of issues before they reached the Court. ${ }^{196}$ By the mid-1970s, some terms had over fifty appeals decided with opinion from three-judge district courts, up to a quarter of the Court's plenary docket. ${ }^{197}$ Throughout the opinion the Court referred, with seeming approval, to the

193. See, e.g., Carol E. Jenson, The Network of Control: State Supreme Courts and State Security Statutes, 1920-1970, at 165 n.31 (1982) (linking Younger v. Harris, 401 U.S. 37 (1971), and other cases limiting powers of federal courts to interfere with state court proceedings with the 1976 limitation on the three-judge district court); John C. Jeffries, Jr. \& George A. Rutherglen, Structural Reform Revisited, 95 CAL. L. REv. 1387, 1395-98 (2007) (tracing restrictions that Congress, with the three-judge district court statute, and the Court, in decisions in the 1970s and 1980s, placed on the injunctive powers of federal courts). The posited linkage to efforts to limit the injunctive powers of the federal courts should not be pressed too far, since limiting the three-judge district court still leaves federal judges free to issue injunctions. See Max Boot, Out of Order: Arrogance, Corruption, and Incompetence on the BENCH 205-06 (1998) (asserting that while by 1976 "all of the pooh-bahs of the legal establishment, led [by Burger]," opposed the three-judge district court, "ostensibly because it created too great a burden on the judiciary ... the real reason was because they didn't like any limits on the power of federal judges"). Indeed, perhaps some of the liberal critics of the court felt that, by the 1970s, individual federal district judges were more likely to issue injunctions against state actions as opposed to a three-judge district court.

194. 419 U.S. 90 (1974).

195. Id. at 98 (footnote omitted).

196. Id. at 98 n.16. See generally Freund RePORT, supra note 189, at 598-99; Solimine, supra note 128, at 108-09. But see ALI STUDY, supra note 128, at 335 (arguing that the direct appeal provision should be retained since Court can use summary dispositions concerning cases "of limited significance," and since other cases "ordinarily turn on questions of law rather than questions of fact, and there is no need for intermediate review to settle the fact questions.").

197. Solimine, supra note 128 , at 138 tbl.2. 
Freund Report and other commentary, which called for repeal or reforms of the authorizing statutes. ${ }^{198}$

By the time Gonzalez was handed down, Congress had been considering reform proposals for several years. ${ }^{199}$ Starting in 1971, several bills of varying provisions were introduced in the House or Senate, ${ }^{200}$ and extensive hearings in the respective Judiciary committees took place in that year and in 1972, 1974, and 1975. ${ }^{201}$ The highlights of the legislative process over three Congresses are the following. Senator Quentin Burdick introduced a bill that

198. Gonzalez, 419 U.S. at 97-98 nn.15-16. Gonzalez was unanimous, as were many of the Court's other decisions narrowly construing the three-judge court statutes. One notable exception was in MTM, Inc. v. Baxley, 420 U.S. 799 (1975) (per curiam). There, the Court held that an appeal from a three-judge district court was only proper when the court had squarely resolved the merits of a constitutional issue. $I d$. at 804 . Justice William O. Douglas was the sole dissenter. In his characteristically gadfly fashion, he acknowledged that he had joined many of the prior restrictive decisions, including Gonzalez, but concluded "that the Court is going too far." Id. at 808 (Douglas, J., dissenting). He discussed the then-ongoing hearings and reform proposals before Congress, and referenced the debate over whether three-judge courts continued "to be an important institution for litigants such as civil rights and welfare plaintiffs." Id. He concluded that Congress, not the Court, should grapple with these policy issues, and that the Court had not aided matters by "twisting" the statutory language. $I d$. at $809-10$.

199. In this period, Congress also abolished certain specialized three-judge district courts, which had been enacted prior to Ex parte Young. See supra note 76. In 1974, Congress passed the Antitrust Procedures and Penalties Act, Pub. L. No. 93-528, 88 Stat. 1706 (codified in scattered sections of 15 U.S.C.), abolishing the convening of three-judge courts in certain antitrust actions. In 1975, Congress passed legislation that repealed the requirement that a three-judge court be convened to review certain I.C.C. actions, Act of Jan. 2, 1975, Pub. L. No. 93-584, 88 Stat. 1917 (codified in scattered sections of 28 U.S.C.). In both cases, it was thought that the use of three-judge district courts in these relatively rare situations was unnecessary. For an overview of the passage of this legislation, see Bennett Boskey \& Eugene Gressman, Recent Reforms in the Federal Judicial Structure-Three-Judge District Courts and Appellate Review, 67 F.R.D. 135 (1975); Jacoby, supra 169, at 44-53. Mark Tushnet has persuasively observed that the "closeness in time" of the 1974, 1975, and 1976 changes to the three-judge court statutes "is largely an artifact," Tushnet, supra note 165 , at 360 , since Congress in each change was responding to different concerns.

200. For a summary of the legislative developments from 1971 to 1975 , see Jacoby, supra note 169 , at 37-42. For brief overviews of the entire legislative process (i.e., up until 1976), see WRIGHT ET AL., supra note $3, \S 4234$, at 188 ; Solimine, supra note 128 , at 85-89.

201. See Diversity Jurisdiction, Multi-Party Litigation, Choice of Law in the Federal Courts: Hearings on S. 1876 Before the Subcomm. on Improvements in Judicial Machinery of the S. Comm. on the Judiciary, 92d Cong. (1971) (pt. 1) [hereinafter 1971 Hearings]; Admiralty Jurisdiction, United States as a Party, General Federal Question Jurisdiction, Three-Judge Courts: Hearings on S. 1876 Before the Subcomm. on Improvements in Judicial Machinery of the S. Comm. on the Judiciary, 92d Cong. (1972) (pt. 2) [hereinafter 1972 Hearings]; Three-Judge Court and Six-Person Civil Jury: Hearing on S. 271 Before the Subcomm. on Courts, Civil Liberties, and the Administration of Justice of the H.R. Comm. on the Judiciary, 93d Cong. (1974) [hereinafter 1973-74 Hearings]; Improvement of Judicial Machinery: Hearings on H.R. 6150 Before the Subcomm. on Courts, Civil Liberties, and the Administration of Justice of the H. Comm. on the Judiciary, 94th Cong. (1975) [hereinafter 1975 Hearings]. 
would have codified the extensive proposals of the ALI study. ${ }^{202}$ In the initial hearings, the Study's recommendations regarding diversity jurisdiction attracted the most attention, and those regarding three-judge district courts received relatively little. ${ }^{203}$ Subsequently, Burdick introduced an amendment to the bill which would limit three-judge courts to reapportionment cases. ${ }^{204}$ The legislative record is unclear regarding the motivation for the amendment, but such luminaries as Judges Henry Friendly and J. Skelly Wright enthusiastically endorsed it in their testimony. They pointed out the various burdens associated with convening such courts and argued that the purported need for the court had come and gone. On the other hand, they suggested that it was appropriate to convene such courts for redistricting cases in order to facilitate issues of "public importance" and, in their view, the "public acceptance" of decisions. Moreover, they stated that the evidence in such cases was likely to be heavily statistical in nature, and that no additional taking of other evidence would typically be necessary. ${ }^{205}$ For his part, Professor Charles Alan Wright opposed the amendment because it did not go far enough. The three-judge court should not be retained even for such cases: although important, reapportionment cases did not, in his view, present purely legal issues, they did require extensive evidentiary hearings. ${ }^{206}$

No further action was taken on the Burdick amendment in the $92 \mathrm{~d}$ Congress. He reintroduced the bill, as amended for three-judge district courts, in the 93rd Congress; ${ }^{207}$ the bill passed the Senate, but no action was taken in the House. ${ }^{208}$ The House, led by Representative Robert Kastenmeier of the Judiciary Committee, held hearings on another Senate bill, ${ }^{209}$ which only addressed three-judge district courts and mirrored the Burdick amendment.

202. 1971 Hearings, supra note 201, at 1-4. Burdick was the chair of the Subcommittee on Improvements in Judicial Machinery of the Senate Judiciary Committee, and had an interest in the ALI STUdy. See, e.g., Quentin N. Burdick, Diversity Jurisdiction under the American Law Institute Proposals: Its Purpose and Effect on State and Federal Courts, 48 N.D. L. REv. 1 (1971). At nearly the same time, Rep. Emmanuel Celler, chairman of the House Judiciary Committee, introduced legislation, H.R. 3805, 92d Cong., 1st Sess. (1971), apparently at the behest of the Judicial Conference, which would have abolished the general three-judge district court. For an extensive discussion of the bill and of the position of the Judicial Conference, see Harris S. Ammerman, Three-Judge District Courts: See How They Run, 52 F.R.D. 293 (1971). No further action on this bill appears to have taken place.

203. 1971 Hearings, supra note 201 (passim).

204. 1972 Hearings, supra note 201, at 745-48.

205. $I d$. at 748-50, 757-61 (testimony of Judge Friendly); id. at 783-92 (testimony of Judge Wright).

206. $I d$. at $772-78$ (testimony of Prof. Wright).

207. S. 1876,93 d Cong. (1973).

208. Jacoby, supra note 169 , at 38 .

209. S. 217 , 93 d Cong. (1973). 
Judge Wright, speaking on behalf of the Judicial Conference, again supported the bill, ${ }^{210}$ as did the American Bar Association, ${ }^{211}$ but what is notable for the first time is the opposition from the civil rights community and their allies. Nathaniel Jones, general counsel of the NAACP, and Clarence Mitchell, director of the Washington office of the organization and a long-time and influential Congressional lobbyist on a variety of issues, argued that the three-judge district court was still necessary. ${ }^{212}$ They contended that constitutional challenges to state practices tested the fortitude of a single district judge from that community, and that the broader perspective of three judges was necessary to give civil rights plaintiffs a fair hearing. ${ }^{213}$ Jones added that the three-judge district court had been, in his view, "a principal vehicle" to enforce the civil rights laws, and the supposed burden of direct appeals from those courts to the Supreme Court was instead evidence that litigation before such courts was still necessary. ${ }^{214}$ The U.S. Civil Rights Commission agreed with the NAACP, ${ }^{215}$ but other civil rights organizations either were not opposed or did not take a position on the proposal. ${ }^{216}$

The pattern repeated itself in the 94th Congress, but this time action did take place. Bills were introduced to restrict the jurisdiction of the three-judge district court to reapportionment cases, ${ }^{217}$ and hearings were held which presented similar testimony to prior hearings. This time, there was a proposal floated, to meet some of the objections, that such courts could be convened when there was a claim of an unconstitutional state or federal statute based on race discrimination, ${ }^{218}$ but that was eventually abandoned. Echoing earlier

210. 1973-74 Hearings, supra note 201, at 4-15 (testimony of Judge Wright).

211. Id. at 101-05 (testimony of Edmund Campbell, Board of Governors, American Bar Association).

212. Nathaniel Jones was later appointed by President Carter to the U.S. Court of Appeals for the Sixth Circuit in 1979, and served on that court until his retirement in 2002. He has the apparently unique status of being the only person to litigate before, testify in Congress about, and serve as a judge on, the three-judge district court. (Conversation by author with Judge Nathaniel Jones, fall 1995.) On Clarence Mitchell, see generally Denton L. Watson, Lion in the Lobby: Clarence Mitchell, JR.'s Struggle For the Passage of Civil Rights Laws (1990); Denton L. Watson, Assessing the Role of the NAACP in the Civil Rights Movement, 55 Historian 453 (1993).

213. 1973-1974 Hearings, supra note 201, at 141-48 (testimony of Nathaniel Jones); id. at 148-49 (testimony of Clarence Mitchell); see also id. at 122-24 (letter from Stanford law professor Anthony G. Amsterdam to Rep. Robert W. Kastenmeier, opposing the bill).

214. Id. at 143 (testimony of Jones).

215. Id. at 149-51 (letter from John A. Buggs, Staff Director, U.S. Civil Rights Commission, to Rep. Robert F. Drinan).

216. Id. at 141 (testimony of Charles Morgan, Jr., American Civil Liberties Union, that the ACLU had no objection to the abolition of the three-court judge).

217. S. 537, 94th Cong., 1st Sess. (1975); H.R. 6150, 94th Cong., 1st Sess. (1975).

218. 1975 Hearings, supra note 201, at 1-2 (testimony of Rep. Kastenmeier). 
hearings, Professor Wright testified in support, and Clarence Mitchell testified in opposition. ${ }^{219}$ The legislation passed and became law in the summer of $1976 .{ }^{220}$ The reports of the Senate and House Judiciary Committees make clear that the drafters of those reports adopted almost all the arguments of the critics of the three-judge district court. That is, the reports reference the administrative burden of convening such courts, the large number of direct appeals to the Supreme Court, and the restrictions placed on federal courts' equity jurisprudence since $1908 .^{221}$ The reports also pointed out that all 50 state attorneys general, representing the supposed beneficiaries of the 1910 statute, had been contacted for their views, and only twelve replied. Of those, only two opposed the restriction of the jurisdiction of the court. ${ }^{222}$ The reports acknowledged the opposition of the NAACP but concluded that "the civil rights of citizens will continue to be well protected by [the] bill.",223 Representative Robert Drinan of the House Judiciary Committee addressed the last point. He noted the large number of authorities, representing diverse constituencies, which either supported or took no position on the restriction. The legislative record, he concluded, did not support the rationales advanced by the NAACP. He also noted that the bill left intact the provisions in the 1964 Civil Rights Act and the 1965 Voting Rights Act, which called for the convening of three-judge district courts under certain circumstances. ${ }^{224}$

Two aspects of this legislative history are noteworthy. One is why the court was left intact to hear reapportionment cases. There were numerous unelaborated references to the "importance" of such cases as deserving the dignity of, and the presumed greater public acceptance of, a three-judge district court, but that rationale could apply to much other public law litigation as well. There was a debate over how burdensome reapportionment litigation would be for such courts, and time has shown that Professor Wright was largely correct. ${ }^{25}$ The reapportionment exception might be seen as a sort of

219. Id. at 156-58, 169-73, 178-79 (testimony of Mitchell); id. at 175-77 (statement of Prof. Wright). 220. Act of Aug. 12, 1976, Pub. L. No. 94-381, 90 Stat. 1119 (codified in part at 28 U.S.C. § 2284).

221. S. ReP. No. 94-204 (1975), as reprinted in 1976 U.S.C.C.A.N.1988, 1991-97 [hereinafter Senate Report]; H.R. Rep. No. 94-1379, at 4 (1976) [hereinafter House Report].

222. Senate Report, supra note 221, at 9-10. The two states were Mississippi and Rhode Island.

223. House REPORT, supra note 221, at 4.

224. Id. at 13-14 (statement of Rep. Drinan); 122 Cong. Rec. 25, 058 (1976) (statement of Rep. Drinan).

225. I elaborate on this point in Solimine, supra note 128, at 91-93, 116 (acknowledging that the number of three-judge district court cases fell after 1976, except for the upsurge of reapportionment cases early in each decade, and arguing that such cases can be factually and legally complex, and sometimes awkwardly litigated before three judges). 
compromise given the opposition of the NAACP. ${ }^{226}$ Also, reapportionment cases were, at the time, particularly controversial. Baker v. Carr and legislative efforts to restrict it were probably fresh in the minds of many members of Congress. ${ }^{227}$ Perhaps some members thought the Baker-inspired federal court litigation had been to their electoral advantage, and sought to preserve it by leaving three-judge district courts intact for such cases. Others may have genuinely thought that such cases were qualitatively more important, and perhaps more difficult, than other public law cases, and thus would benefit from the current regime of three trial judges with a direct appeal to the Supreme Court. ${ }^{228}$ Also, federal judges Friendly and Wright had advocated leaving the court intact for reapportionment cases. Perhaps they realized that federal judges were perceived as deciding such cases along partisan lines, and that a multimember court might give cover to individual jurists in such circumstances. ${ }^{229}$

226. Id. at 89 . Characterizing it as a "compromise" may be misleading, since it appears from the legislative record that the NAACP did not consent to the restriction to reapportionment cases. While the NAACP and other civil rights organizations were of course involved in voting rights litigation and legislation, see, e.g., Richard C. Cortner, The ApPoRTIONMENT CASEs 84-85 (1970) (discussing NAACP representing plaintiff in Supreme Court in Gormillion v. Lightfoot, 364 U.S. 339 (1960) (racial gerrymandering case)), it does not appear that they were particularly concerned with reapportionment cases as such. This is not to say that there was not continuity between race relations and reapportionment cases, since malapportionment was seen as detrimental to the interests of urban African-Americans. WASBY ET AL., supra note 137, at 225-26; David J. Garrow, Bad Behavior Makes Big Law: Southern Malfeasance and the Expansion of Federal Judicial Power, 1954-1968, 82 ST. JoHn's L. REv. 1, 18-21 (2008).

227. FALLON ET AL., supra note 7, at $321 \& \mathrm{n} .14$ (pointing out that after Baker over 50 bills were introduced in Congress to limit federal court adjudication in reapportionment cases, one of which passed the House). While the initial reaction to the reapportionment cases was, at least among federal and state legislators, quite hostile, in time the decisions came to be widely accepted. Barry Friedman, The Birth of an Academic Obsession: The History of the Countermajoritarian Difficult, Part Five, 112 YaLE L.J. 153, 206-09 (2002); Garrow, supra note 226, at 20-21.

228. Michael E. Solimine, The Causes and Consequences of the Reapportionment Revolution, 1 ELECTION L.J. 579 (2002) (book review) (discussing reapportionment litigation in the 1960s and 1970s); Keith E. Whittington, "Interpose Your Friendly Hand": Political Supports for the Exercise of Judicial Review by the United States Supreme Court, 99 Am. PoL. SCI. Rev. 583, 587-89 (2005) (arguing that liberals supported reapportionment litigation because it enabled them to achieve policy goals unattainable by other means).

229. Solimine, supra note 161 , at $789 \&$ n.99 (giving examples of perception or assumption of partisan voting by federal judges in election law cases). Whether federal judges in fact vote in a systematic partisan fashion in reapportionment and related voting rights cases is the subject of ongoing study. See, e.g., Adam B. Cox \& Thomas J. Miles, Judging the Voting Rights Act, 108 Colum. L. Rev. 1 (2008); Solimine, supra note 161, at 789-91. Separately, there is some evidence that Chief Judges of circuits seek some political balance when naming the members of three-judge district courts in reapportionment cases. Solimine, supra note 128, at 113-15. 
More intriguing is the inability of the NAACP and its allies to prevent passage of the bill. The NAACP did not lack for success before Congress on a variety of issues involving the federal courts, neither contemporaneous with nor after the passage of the revision to the three-judge district court statute. ${ }^{230}$ A confluence of reasons is behind this particular setback for the NAACP. The first and probably most important is that while the NAACP officials eloquently presented their claim that the three-judge district court was still necessary for civil rights enforcement, they ultimately did not make a sufficient factual case before Congress or elsewhere to rebut the claims of the critics of the court. They relied almost exclusively on historical or anecdotal evidence of the purported need for such courts, and did relatively little to counter the claims of administrative burdens at both the trial and Supreme Court levels. ${ }^{231}$ As it happens, the NAACP's agenda was full at the time, primarily responding to what it regarded as various unfavorable initiatives of the Republican executive branch from 1969 to $1977 .{ }^{232}$ Their usual political

230. For example, the NAACP's Mitchell played a prominent role in lobbying for the legislation passed in 1976, codified at 42 U.S.C. $§ 1988$, which provided for the awarding of attorneys fees to prevailing plaintiffs in certain civil rights cases. Armand Derfner, Background and Origin of the Civil Rights Attorney's Fee Awards Act of 1976, 37 Urb. LAw. 653 (2005); Karen O'Connor \& Lee Epstein, Bridging the Gap Between Congress and the Supreme Court: Interest Groups and the Erosion of the American Rule Governing Awards of Attorneys' Fees, 38 W.PoL. Q. 238 (1985). In the 1970s, the NAACP and other civil rights organizations also opposed the breakup of the old Fifth Circuit, since many of the appellate judges on that court had been hospitable to their interests. That opposition succeeded in delaying until 1980 the breakup into the new Fifth and Eleventh Circuits, and influenced the substance of the eventual legislation. BARROW \& WALKER, supra note 142, at 194-96, 239-41.

231. For example, Mitchell referred to an arguably idiosyncratic employment discrimination case brought by the NAACP LDF and held for the defendant, Robinson v. Union Carbide Corp., 380 F. Supp. 731 (S.D. Ala. 1974), aff'd in part, rev'd in part, 538 F.2d 652 (5th Cir. 1976), cert. denied, 434 U.S. 822 (1977), as a case that would likely have come out differently if it had been decided by a three-judge district court. 1975 Hearings, supra note 201, at 157-69 (The district judge in that case, William Brevard Hand, was appointed by President Nixon in 1971. He later achieved notoriety by holding that the Establishment Clause was not meant to apply to the states. Jaffree v. Bd. of Sch. Comm'rs, 554 F. Supp. 1104 (S.D. Ala.), rev'd, 705 F.2d 1526 (11th Cir. 1983), aff'd, 466 U.S. 924 (1984)). The critics of the revision of the threejudge district court might have drawn on then-existing, published empirical evidence which could have been characterized as suggesting that there was a systematic difference between the results of cases before a single district judge, and a three-judge district court, with the latter favoring civil rights plaintiffs. See supra notes 144-47 \& accompanying text. At the request of a staffer on the Senate Judiciary Committee, the authors of that research prepared a memo summarizing their forthcoming publications. See Thomas G. Walker \& Eleanor C. Main, Research Report Submitted to the Senate Judiciary Committee: The DecisionMaking Impact of the Federal Three-Judge Court Act of 1910 (1972) (on file with author). I am grateful to Tom Walker for providing me with a copy of this report. Apparently, no use was made of the report (E-mail from Thomas G. Walker, Professor of Political Science, Emory University, to Michael E. Solimine, Professor of Law, University of Cincinnati College of Law (Aug. 28, 2007) (on file with author)), and I did not find any references to it in the legislative record.

232. See Clarence Mitchell, Quarterly Report of the Washington Bureau, NAACP (Mar. 25, 1974) 
prowess was diluted by being directed at many targets besides that of the three-judge district court bills.

But it seems doubtful that even a more fully energized civil rights lobby would have prevailed. Arrayed against them on this issue were several high profile institutions, including the Supreme Court, the Judicial Conference, and the ALI. This was not the first time the Court had actively lobbied Congress on an issue pertaining to its own jurisdiction (consider the Judges' Bill fifty years earlier), but it was a time when the Judicial Conference was becoming particularly active as an advocacy group. ${ }^{233}$ A Congress with Democratic majorities might be thought to have been sympathetic to the views of the NAACP, but that was blunted by Democratic leaders' acceptance of the criticisms of maintaining the status quo for three-judge district courts. ${ }^{234}$ This fact was made particularly clear when Rep. Robert Drinan, a Congressman clearly sympathetic to the concerns of the civil rights lobby, ${ }^{235}$ openly

(memorandum discussing anti-busing proposals in Congress and various other legislative and executive issues, with a brief discussion of the bills to revise the three-judge district court) (on file with author). I am grateful to Denton Watson, Clarence Mitchell's biographer, for providing this memo. Cf. Miller, supra note 153, at 45 (criticizing the "ineptness, haziness, confusion and division among" the civil rights activists opposed to the restrictions on the three-judge district court). For discussion of the varied activities of the NAACP during this period, mostly working against initiatives of the Nixon and Ford Administrations, see Dean J. Kotlowski, Nixon's Civil Rights: Politics, Principle, And Policy 65, 104, 111, 175 (2001); WATSON, supra note 212, at 725-43; Lawrence J. McAndrews, Missing the Bus: Gerald Ford and School Desegregation, 27 PRes. STUD. Q. 791, 800 (1997). It is worth noting here that the Nixon and Ford administrations played a minor role in the debate over restricting the court, though both supported the proposed restrictions. 1973-74 Hearings, supra note 201, at 81-87 (testimony of Robert G. Dixon, Jr., Assistant Attorney General, Office of Legal Counsel, U.S. Department of Justice).

233. For a thorough and critical examination of the growth and success of the lobbying activities of the Judicial Conference, see Judith Resnik, Trial as Error, Jurisdiction as Injury: Transforming the Meaning of Article III, 113 Harv. L. Rev. 924, 949-95 (2000). See also Peter Graham Fish, The Politics of Federal Judicial Administration 301-09 (1973) (detailing lobbying of Congress by the Judicial Conference).

234. In particular, in their respective chambers Sen. Burdick (see supra note 202) and Rep. Kastenmeier, the chair of the House Subcommittee on Courts, Civil Liberties, and the Administration of Justice, were particularly interested in the reforms to the institutional structures of the federal courts (see, e.g., Robert W. Kastenmeier \& Michael J. Remington, A Judicious Legislator's Lexicon to the Federal Judiciary, in Judges and Legislators: Toward Institutional Comity 54 (Robert A. Katzmann ed., 1988)), and in restricting the three-judge district court comfortably within that agenda.

235. Contemporary accounts give weight to the support of Rep. Drinan for the 1976 legislation. E.g., Robert M. Smith, 3-Judge Court Use for U.S. Cases Cut, N.Y. TimEs, Aug, 13, 1976, at A9; Miller, supra note 153, at 53-54. In addition to his support of many civil rights causes, it is worth noting that Drinan was a member of the board of directors of the NAACP. Robert D. Rotunda, Remembering Robert F. Drinan, S.J., 20 Geo. J. Legal Eтhics 203, 205 (2007). A similar observation can be made about Rep. Kastenmeier's support of the restriction of the court, given his support of much of the balance of the civil rights agenda. Frank Tuerkheimer, Bob Kastenmeier and 1960s Civil Rights Legislation: Leadership Through Commitment and Foresight, 2005 WIs. L. ReV. 947 (2005). 
disagreed with the views of the NAACP. The same can be said of the views of other liberal icons, such as Judge Skelly Wright. By the mid-1970s, there had been turnover in the federal bench from the heyday of the civil rights movement, ${ }^{236}$ and perhaps there was a sense that the value of the three-judge district court was disproportionately restricted to the Deep South. ${ }^{237}$ Even that concern was less compelling as the fervor for the civil rights movement generally lessened by $1976 .^{238}$

\section{E. Downsized, but Not Out}

The downsizing of the three-judge district court left the court intact to hear reapportionment cases, and there the court has led an active life. ${ }^{239}$ And litigation before such courts unaffected by the 1976 statute, such as preclearance actions under the 1965 Voting Rights Act, lives on. Moreover, Congress has from time to time created special three-judge district courts to litigate the constitutionality of particular federal statutes, largely for the reasons it extended the jurisdiction of the court in 1937. That is, for particular statutes Congress may conclude that three federal judges should initially consider the sensitive and contentious issues raised by a constitutional challenge to certain statutes, and that a rapid resolution of such questions would be facilitated by a direct appeal to the Supreme Court. ${ }^{240}$

236. Deborah J. Barrow et al., The Federal Judiciary and Institutional Change 65-70 (1996) (discussing general judicial turnover in the Nixon/Ford administrations); Micheal W. Giles \& Thomas G. Walker, Judicial Policy-Making and Southern School Desegregation, 37 J. PoL. 917, 935 (1975) (discussing turnover of federal judges in the South during this period). Relatedly, since the Fifth Circuit as a whole during much of the 1960s and 1970s was relatively sympathetic to plaintiffs in civil rights cases, while the Burger Court was becoming less so, it seems curious that the NAACP was so critical of the curtailment of direct review to the Supreme Court. Miller, supra note 153, at 68. Indeed, it was the perceived sympathy of the Fifth Circuit that led the NAACP and others to oppose the breakup of the old Fifth Circuit. Hellman, supra note 192, at 345.

237. The Annual Reports of the Administrative Office of the U.S. Courts has collected data on the number of "hearings" each year before three-judge district courts. To get a sense of the geographic dispersion of cases before such courts involving civil rights actions, I conducted a computer search on Westlaw to capture published opinions from such courts involving "civil rights," "race discrimination," and related terms, decided from 1951 to Jan. 1, 1976. The search yielded 372 opinions and, of those, 35\% were from one of the six states of the former Fifth Circuit. The figure rises to $43 \%$ for the opinions decided between 1951 and Jan. 1, 1970 (a list of cases is available from the author).

238. Disputes over busing, affirmative action, and other issues blunted further Congressional initiatives on civil rights in the 1970s. Nina M. Moore, Governing Race: Policy, Process, And the Politics of Race 81-107 (2000); James T. Patterson: Restless Giant: The United States From Watergate to BUSh V. GORE 15-32 (2005).

239. IsSACHAROFF, supra note 159 , at 737 ; Solimine, supra note 161 , at 783 .

240. For enacted examples, see Gressman ET AL., supra note 134, at 102-03 (referring to ten statutes 
A prominent recent example of such a statute is the Bipartisan Campaign Reform Act (BCRA) of 2002, otherwise known as the McCain-Feingold law. The BCRA provides that any constitutional challenge must be filed, and litigated expeditiously, in the U.S. District Court for the District of Columbia, with a direct appeal to the Supreme Court. ${ }^{241}$ The legislative history of this portion of the BCRA is sparse, but it appears that the drafters believed that litigation over legislation governing campaigns for federal office needed to be promptly resolved, and that the controversial First Amendment issues raised by an expected challenge would be better considered by three trial judges rather than one. ${ }^{242}$ Whether the actual litigation that culminated in the Supreme Court's decision in McConnell v. FEC ${ }^{243}$ satisfied these goals is an open question. The litigation started promptly enough (the same day the President signed the legislation), but it became bogged down in discovery and other proceedings at the district court. The court issued a lengthy opinion over a year after suit was filed, a direct appeal followed, and the Supreme Court's decision was issued eight months later. ${ }^{244}$ The McConnell litigation did not exhaust all constitutional challenges to the various provisions of the BCRA, and further cases have been litigated before the three-judge district court and the Supreme Court. ${ }^{245}$

Congress has also placed three-judge district court provisions in bills that were not enacted. ${ }^{246}$ The reasons are typically those that attended the passage of enacted provisions like the BCRA. ${ }^{247}$ Then, too, some of these provisions

passed since 1986).

241. Pub. L. 107-155, § 403(a), 116 Stat. 113 (2002) (codified at 2 U.S.C. $§ 437$ (a) (Supp. 2004))

242. For a discussion of the legislative history of the provision, see Solimine, supra note 161, at $772-75$.

243. McConnell v. FEC, 540 U.S. 93 (2003).

244. Solimine, supra note 161, at 776-78 (providing details of the McConnell litigation).

245. See Wis. Right to Life v. FEC, 546 U.S. 410 (2006) (WRTL I); Christian Civic League of Me. v. FEC, 433 F. Supp. 2 d 81 (D.D.C. 2006), dismissed as moot, 127 S. Ct. 336 (2006); Wis. Right to Life v. FEC, 127 S. Ct. 2652 (2007) (WRTL II); Davis v. FEC, 501 F. Supp. 2d 22 (D.D.C. 2007) (three-judge court), rev'd, 128 S. Ct. 2759 (2008); Citizens United v. FEC, 530 F. Supp. 2d 274 (D.D.C.) (three-judge court), dismissed, 128 S. Ct. 1732 (2008).

246. See, e.g., Solimine, supra note 128, at 129-30 (discussing bills which required that a three-judge district court be convened to hear a constitutional challenge to a state referendum); S. 2468, 109th Cong. (2d Sess. 2006) (permitting civil action to challenge the constitutionality of certain warrantless, electronic surveillance for foreign intelligence devices to be brought before a three-judge district court in the District of Columbia, with a direct appeal to the Supreme Court).

247. For example, the Fairness in Asbestos Injury Resolution Act of 2005, S. 852, 109th Cong. $\S 305(\mathrm{c})(1)$ (1st Sess. 2005), required that any constitutional challenge to the compensation scheme established by the Act be brought in a three-judge district court in the District of Columbia, with a direct appeal available to the Supreme Court. The provision was modeled after the BCRA provision. S. REP. No. 109-97, at 182 (2005) (Conf. Rep.) (additional views of Sen. Feinstein). See also Jamal Greene, Giving the 
may have been the result of implicit deals between supporters and even opponents of the proposed legislation when a constitutional challenge is expected. ${ }^{248}$ For these reasons, the three-judge district court continues to enjoy a relatively active life, even beyond the reapportionment litigation referenced in the 1976 amendment.

\section{Conclusion: The Three-Judge District Court and the Vortex of the Relationship Between the Supreme Court and Congress}

For over two centuries, there have been numerous and myriad ways that the judicial branch-particularly, though not limited to, the Supreme Court - has interacted with Congress. The most high profile example is the Senate giving its advice and consent to the President's judicial nominations. Congress has also periodically increased the number of lower court judges. Other examples would include reaction to specific Supreme Court decisions, initiation of the Constitutional amendment process, and amendment of statutes interpreted by the Court. More pertinent to the present article, Congress can by statute also expand or restrict the appellate jurisdiction of the Supreme Court, or the jurisdiction of the lower federal courts. Likewise, Congress can expand or restrict the remedies that federal judges may issue. ${ }^{249}$ There is a large amount of academic literature examining legal issues raised by these reactions, such as whether Congress has the constitutional authority to restrict the jurisdiction of or the remedies issued by federal courts. ${ }^{250} \mathrm{~A}$ similarly

Constitution to the Courts, 117 YALE L.J. 886, 897 (2008) (book review) (discussing "the growing prevalence of statutory provisions for expedited Supreme Court review.").

248. Solimine, supra note 161, at 773-75 (discussing this possibility in the context of the BCRA). A twist of this phenomenon might be in the reauthorization in 2006 of the expiring provisions of the 1982 amendments to the Voting Rights Act. There was extensive discussion in Congress of the possible constitutional problems attending the reauthorization of the preclearance provisions in section 5 . However, no special reviewing court was established, as it was apparently assumed that any such challenge would be brought before the three-judge district court in the District of Columbia, which hears preclearance actions under section 5. For further discussion, see Solimine, supra note 161, at $774 \mathrm{n} .26$. That court recently upheld the constitutionality of the 2006 reauthorization. Nw. Austin Mun. Util. Dist. No. One v. Mukasey, 557 F. Supp. 2 d 9 (D.D.C. 2008) (three-judge court).

249. For overviews of the numerous ways the federal judicial branch as a whole, and the Supreme Court in particular, interacts with Congress, see Charles Gardner GeyH, When Courts \& Congress Collide: The Struggle for Control of America's Judicial System (2006); Jeb Barnes, Bringing the Courts Back In: Interbranch Perspectives on the Role of Courts in American Politics and Policy Making, 10 Ann. Rev. Pol. Scr. 25 (2007); Brett Curry, Institutions, Interests, and Judicial Outcomes: The Politics of Federal Diversity Jurisdiction, 60 PoL. Res. Q. 454, 455-56 (2007); Whittington, supra note 228, at 584.

250. For an overview of and contribution to this large literature, see FALLON ET AL., supra note 7, at 
abundant amount of literature by social scientists has empirically documented these Congressional actions and examined, among other things, the timing and motivations of these responses. ${ }^{251}$

Deborah Barrow and Thomas Walker have suggested that there are several common characteristics associated with modern efforts by Congress to address institutional aspects of the federal courts. ${ }^{252}$ Many statutory changes to the jurisdiction or other institutional aspects of federal courts are the result of cooperative oversight between Congress and the judicial branch. Typically, a change will come from the identification of a problem, often by the judicial branch itself through the Judicial Conference. The Judiciary Committees of Congress are usually assigned the primary responsibility to consider responses to the problem. The executive branch rarely plays an important role in such deliberations. ${ }^{253}$ These patterns are not surprising. The judicial branch will usually have the most information and expertise about its own needs and concerns, as compared to Congress. Members of Congress and their staffs, and even the Judiciary Committees, often defer to the judicial branch in this regard. ${ }^{254}$ In general, they give a low priority to issues regarding judicial administration, since there is little constituency for it and since it does not aid in the members' reelection. The President will have other high-profile issues on his agenda, and usually acquiesces in the other branches taking the initiative. ${ }^{255}$ But Congressional and Executive deference does not guarantee that bills dealing with judicial legislation, much less any other topic, will

319-61. For some recent additions to this literature, see Steven G. Calabresi \& Gary Lawson, The Unitary Executive, Jurisdiction Stripping, and the Hamdan Opinions: A Textualist Response to Justice Scalia, 107 Colum. L. Rev. 1002 (2007); Helen Norton, Reshaping Federal Jurisdiction: Congress's Latest Challenge to Judicial Review, 41 Wake Forest L. Rev. 1003 (2006); James E. Pfander, Federal Supremacy, State Court Inferiority, and the Constitutionality of Jurisdiction-Stripping Legislation, 101 Nw. U. L. REv. 191 (2007).

251. For overviews of this large literature, see Lawrence Baum, The Supreme Court 203-08 (9th ed. 2007); GeYH, supra note 249; Keith E. Whittington, James Madison Has Left the Building, 72 U. CHI. L. REv. 1137 (2005) (book review). For some recent additions to the literature, see Lauren C. Bell \& Kevin M. Scott, Policy Statements or Symbolic Politics? Explaining Congressional Court-Limiting Attempts, 89 JudiCATURE 196 (2006) (study of court-limiting bills introduced in Congress from 1973 to 2000); Nancy C. Staudt et al., Judicial Decisions as Tax Legislation: Congressional Oversight of Supreme Court Tax Cases, 1954-2005, 82 N.Y.U. L. Rev. 1340 (2007) (empirical study of Congressional response to Supreme Court statutory tax decisions).

252. They drew these conclusions from their extensive analysis of the process, which culminated in the breakup of the Fifth Circuit in 1980 into a Fifth Circuit and a new Eleventh Circuit. BARROw \& WALKER, supra note 142, at 246-49.

253. Id. at 248-52.

254. Mark C. Miller, Congressional Committees and the Federal Courts: A Neo-Institutional Perspective, 45 W. PoL. Q. 949, 959-62 (1992).

255. BARROW \& WALKER, supra note 142, at 252-54. 
result in enacted legislation. Here, as in other areas, "policy adoption depends to a great extent on the sponsorship of an interested and influential legislator" who takes the lead in "shepherding the proposal through the legislative process. ${ }^{" 256}$ As part of that process, members of the judicial branch and their allies must often formally and informally lobby the appropriate members of and committees in Congress. ${ }^{257}$

The 1910 statute that established the three-judge district court to consider requests for Ex parte Young-type relief defies easy characterization as a court-curbing measure. As a formal matter, it did not restrict federal court jurisdiction at all, or prescribe any particular relief ordered by a federal judge. Instead, it created a temporary specialized court for a particular set of cases, drawn from the existing pool of Article III federal judges. It was meant to make it more difficult for litigants to obtain injunctive relief under Ex parte Young, but the response was indeed muted, as the 1910 statute only governed the procedure and arrangements under which that relief could be obtained. The relief was still available, and it blossomed as a remedy in the federal courts in the latter part of the last century.

But the general pattern of Congressional regulation of federal court jurisdiction does illuminate the birth and aging of the three-judge district court. The process described by Barrow and Walker is one most emblematic of the post-World War II era. The 1910 statute appears to have been driven almost entirely by ideological disagreements with Supreme Court decisions striking down state regulatory practices. Even here, Congress was not in a particular uproar, and the statute's passage can be largely attributed to the efforts of Senator Overman. There was relatively little discussion of the administrative burdens attending the creation of such a court, and virtually no input on the propriety of the law from the federal judiciary itself. ${ }^{258}$ The 1937 statute, which extended the court's coverage to constitutional challenges to federal statutes, similarly was primarily driven by Congress's negative reaction to the federal court adjudication of New Deal legislation.

The 1976 statute was a contrast to those efforts. It was characteristic of a general change in Congressional concerns with federal court jurisdiction,

256. Id. at 256 .

257. Id. at 257-62. For a similar broad-ranging analysis of federal jurisdictional reform by Congress, see Edward A. Purcell, Jr., The Class Action Fairness Act in Perspective: The Old and the New in Federal Jurisdictional Reform, 156 U. PA. L. REv. (forthcoming 2008) (manuscript at 3-25, on file with author).

258. The Judicial Conference was only created in 1922, and only began its lobbying in earnest some years after that. Resnik, supra note 233, at 949-66 (discussing the creation of the Judicial Conference and its subsequent activities). 
from focusing on the outcomes of cases in the federal courts, to greater attention to administrative concerns. This is especially true where the types of cases in question recede in controversy and salience. ${ }^{259}$ The process that culminated in the 1976 statute is illustrative. There were calls from the early 1960s to abolish the three-judge district court or restrict its coverage, but the use of the court during the Civil Rights Era did not make it an opportune time for Congress to undertake a serious reappraisal. Indeed, in the 1964 Civil Rights Act and the 1965 Voting Rights Act, Congress added, if only modestly, to the types of cases that came before such courts. By the early 1970s, the importance of facilitating civil rights litigation had waned, and administrative concerns gained more attention. The Supreme Court and its allies lobbied Congress to change the law and, with the aid of advocates with unassailable liberal credentials, were able to overcome the opposition of the NAACP. The executive branch played a minor role, ${ }^{260}$ and the statutory change benefited from the attention of Senator Burdick and Representative Kastenmeier. ${ }^{261}$

Over four decades ago, David Currie observed that "the three-judge provisions, despite their bland and technical phrasing, are products of battles between competing political forces over four persistent and significant issues: judicial review, national supremacy, sovereign immunity, and the use of the injunction." ${ }^{262}$ The Court's decision in Ex parte Young, if it did not initiate the battle, led to its escalation and the creation of the three-judge district court. The battle ended on a quieter and different note seventy-five years later when Congress, with the enthusiastic support of the Court and the rest of the federal judiciary, severely restricted the number of times three-judge district courts would need to be convened. Skirmishes continue to the present day with respect to reapportionment and a handful of other cases. The fate of the three-judge district court remains to be determined by future Congresses.

259. Robert M. Cover, The Uses of Jurisdictional Redundancy: Interest, Ideology, and Innovation, 22 WM. \& MARY L. REV. 639, 645 (1981) (discussing how "the impulse to use three judges instead of one, which arose out of norm articulation concerns, [eventually] ran counter to standards of efficient dispute resolution."); Curry, supra note 249, at 462-64 (discussing the change from ideological to administrative concerns with regard to Congressional changes to diversity jurisdiction in the last century).

260. See supra note 232.

261. It is worth noting that both Sen. Burdick and Rep. Kastenmeier reprised these roles to a degree in the process which culminated in the splitting of the old Fifth Circuit in 1980, see BARROW \& WALKER, supra note 142 , at $159-60,171-76,256$, which as a matter of policy and timing resembled that which led to the 1976 statute on the three-judge district court.

262. Currie, supra note 54 , at 3. 